\title{
Spatial heterogeneity of phytoplankton assemblages in tidepools: effects of abiotic and biotic factors
}

\author{
Anna Metaxas*, Robert E. Scheibling \\ Department of Biology, Dalhousie University, Halifax, Nova Scotia, Canada B3H 4J1
}

\begin{abstract}
In any ecological system, the factors that regulate the abundance of species vary with spatial scale; therefore, the sources of spatial variability should be described. We examined different sources of variability in the spatial distribution of phytoplankton assemblages and biotic (e.g. planktonic and benthic micrograzers, mussels) and abiotic (e.g. nutrients, temperature, salinity, pH) factors that may regulate these assemblages in 4 tidepools at each of 3 intertidal zones (mid, high and splash) on a rocky shore in Nova Scotia, Canada, over a period of 15 mo. Stratum (defined as the depth within a pool) was a significant source of variability, particularly for pennate diatoms which were consistently more abundant near the bottom of pools. There was no indication of vertical zonation of the phytoplankton assemblages along the intertidal gradient, and differences among zones rarely explained more than $30 \%$ of the spatial vanabilıty in phytoplankton abundance. Also, among-zone variation was not apparent for the biotic and abiotic factors. We suggest that among-zone variability in these factors does not adequately explain vertical variability in phytoplankton assemblages. All groups of phytoplankton varied significantly among pools within intertıdal zones on most sampling dates, and differences among pools explained up to $96 \%$ of the variability in phytoplankton abundance. Furthermore, there was significant variability among pools within zones for all brotic and abiotic characteristics of the pools on most sampling dates. We detected significant relationships between the density of benthic micrograzers and small mussels, and the concentration of nutrients in individual pools with the abundance of pennate diatoms, cryptomonads and chlorophytes. Among the abiotic characteristics of the tidepools, there was a significant relationship between flushing rate and temperature of individual pools, with the abundance of cryptomonads and chlorophytes. We suggest that the factors that regulate phytoplankton assemblages in tidepools probably operate more at the scale of the individual pool rather than the intertidal zone.
\end{abstract}

KEY WORDS: Community regulation - Community structure - Intertidal gradient Phytoplankton .

Spatial scales · Tidepools · Zonation

\section{INTRODUCTION}

The importance of spatial variability in ecological processes and community organization has been emphasized in recent studies (Addicott et al. 1987, Wiegert 1988, Wiens 1989). In any ecological system, different patterns of species abundance and community organization emerge at different spatial scales of

- Present address: Department of Larval Ecology, Harbor Branch Oceanographic Institution, 5600 U.S. 1 North, Fort Pierce, Florida 34946, USA. E-mail: metaxas@hboi.edu investigation and the relative importance of smallscale phenomema versus broader-scale processes indicates the 'openness' of the system (Wiens 1989). Levin (1992) recommended that patterns of variability in community organization within and across systems must be described if prediction of community dynamics is to be successful. Both the small-scale phenomena and the broad-scale processes that affect an ecological system have to be defined before their relative importance can be assessed. The importance of sampling procedures in examining variability at different spatial scales has been emphasized (see Andrew \& Mapstone 
1987 for review) and statistical and numerical models have been developed that examine the different sources of spatial variability (e.g. Morris 1987, Perry 1988. Downes et al. 1993).

Community structure and organization have been studied extensively on rocky intertidal shores (e.g Stephenson \& Stephenson 1950, 1952, 1954a, b, Dayton 1971, Connell 1972, Menge 1976. Underwood 1.981a). Research on this system has provided useful concepts, empirical evidence and models that are applicable to many other communities (e.g. Paine 1966, Connell 1983, Sousa 1984a, b). Studies of community structure of rocky intertidal shores have largely focussed on the ubiquitous vertical zonation of organisms along the intertidal gradient (e.g. Connell 1961, Dayton 1971, Paine 1974, Lubchenco \& Menge 1978, Schonbeck \& Norton 1978, Denley \& Underwood 1979). Recent studies, however, have attempted to identify and describe potential sources of natural variability at different spatial scales (from meters to kilometres) (e.g. Underwood \& Denley 1984, Caffey 1985, Jernakoff \& Fairweather 1985, McGuinness 1987a, b, Foster 1990, Lively et al. 1993). These studies have shown that spatial variability on rocky intertidal shores does not change monotonically with scale, i.e. variability does not always increase or decrease at larger spatial scales. The extent to which small-scale variability can affect the outcome of large-scale processes has not been established yet.

Tidepools are a conspicuous component of the rocky intertidal habitat that are less frequently studied than the emergent substrata. However, because of their well-defined boundaries and manageable size, tidepools provide a useful system for examining sources of variability at different spatial scales. The biological zonation which characterizes the emergent substrata is not as apparent in tidepools isee Metaxas \& Scheibling 1993 for review, Metaxas \& Scheibling 1994a, Metaxas et al. 1994. J. Spatial variability in community structure is probably larger among pools than among locations on the emergent substrata at the same spatial scale since the physical characteristics of tidepools (e.g pool depth, volume, orientation and flushing rate) make individual pools unique (Metaxas \& Scheibling 1993). Metaxas \& Scheibling (1994a) and Metaxas et al. (1994) showed that small-scale variability among pools within intertidal zones may mask the broader-scale zonation observed on emergent substrata, at least for some functional groups of macroand hyperbenthos.

Microalgae, particularly pennate diatoms, are among the first colonizers of bare rocky intertidal shores (Sousa 1979, MacLulich 1986) and may exhibit vertical zonation on emergent substrata. Earlier studies have shown that some benthic diatoms, such as the pennate diatom Acnanthes, are more abundant higher on the shore while others, such as the centric diatom Melosira, are more abundant lower on the shore (Aleem 1950, Castenholz 1963. Hopkins 1964). Recently, however, Hill \& Hawkins (1991) found large horizontal spatial variability in the abundance of epilithic diatoms on a rocky shore on the Isle of Man, UK.

Very few studies have examined the distribution and abundance of microalgae in tidepools on rocky shores (see Metaxas \& Scheibling 1993). Droop (1953) provided a classification of pools on the basis of their phytoplankton assemblages which varied along the intertidal gradient. Metaxas \& Lewis (1992) found that the abundance of centric diatoms decreased in pools higher on the shore while that of pennate diatoms tended to increase. Neither of these studies, however, used replicate pools within zones to determine whether the observed pattern would persist across space. Dethier (1984) used a large number of tidepools and found that diatoms were more abundant in lower pools of protected shores. However, she did not quantify horizontal spatial variability and only examined the diatom community of the benthos, not the water column of the pools.

It is well established that phytoplankton community structure in large aquatic systems such as lakes and the open ocean can be directly affected by nutrients and/or herbivory. Spring and fall phytoplankton blooms are triggered by increased nutrient concentrations in the euphotic zone after vertical mixing; blooms collapse because of nutrient depletion, cell sinking or increased grazing (e.g. reviews in Reynolds et al. 1982, Harrison et al. 1983, Reid et al. 1990, Sommer 1991, Wassman 1991). The growth of different groups of phytoplankton is limited in different nutrient regimes and species can coexist when limited by different resources (Tilman 1977, but see Hobson 1988/1989). Conversely, nutrient uptake rates and efficiency vary among different groups of phytoplankton, and the nutrient levels in the environment can determine patterns of dominance and succession (Parsons et al. 1978, Vanni \& Temte 1990, Gervais 1991, Pomeroy 1991, Sommer 1991) Selective grazing also may result in shifts in phytoplankton dominance (Vanni \& Temte 1990, Gervais 1991, Sommer 1991).

In tidepool systems, microalgae are introduced through input from the surrounding seawater, by the ascending tide and through spray. The microalgal assemblages subsequently become isolated from external input for extended periods of time, depending upon the period of isolation of the pool. During this period, the assemblage may change due to a number of factors (Metaxas \& Scheibling 1994b). Phytoplankton may remain suspended because of buoyancy or motility (e.g. centric diatoms, flagellates, nanoflagel- 
lates) or may sink to the bottom (e.g. benthic centric and pennate diatoms). Phytoplankon may be consumed by macrobenthic filter-feeders such as mussels, or planktonic filter-feeders such as calanoid copepods and rotifers. Benthic micrograzers such as harpacticoid copepods may consume microalgae that have sunk to the bottom of the pool. The nutrient regime can change either through uptake by micro- and macroalgae or through excretion by the fauna. The physical conditions of the pools can change and may even reach lethal limits for certain groups of microalgae. The magnitude of changes affecting the phytoplankton assemblage will depend on the length of the period of tidal isolation of the pool. Predictable zonation patterns may arise if the magnitudes of change are similar among pools with similar periods of isolation (within the same intertidal zone). However, horizontal spatial variability among pools within zones may mask the broad-scale phenomenon of zonation.

We examined the sources of vertical and horizontal spatial variability of phytoplankton assemblages in tidepools located in 3 intertidal zones over a period of 16 mo. Specifically, we wanted to determine whether the broad-scale phenomenon of intertidal zonation is evident in these assemblages, or whether the horizontal spatial variability in the abundance of phytoplankton among tidepools within intertidal zones overrides any pattern of zonation. We also measured the sources of spatial variability in the nutrient regime, the grazer field, and in a number of abiotic characteristics of the tidepools to determine whether variability in abiotic and biotic factors could explain the observed patterns of phytoplankton abundance at these spatial scales.

\section{MATERIALS AND METHODS}

Four tidepools at each of 3 intertidal zones (mid, high and splash) were sampled at Cranberry Cove, an exposed rocky shore near Halifax, Nova Scotia, Canada $\left(44^{\circ} 28^{\prime} \mathrm{N}, 63^{\circ} 56^{\prime} \mathrm{W}\right)$ at approximately monthly intervals between March 1991 and June 1992. We did not sample between December 1991 and March 1992 because the pools were frozen during this period. The shoreline consists of granitic platforms and large outcrops with a 10 to $30 \%$ grade. It has a southern exposure to aceanic swells which may reach wave heights of up to $10 \mathrm{~m}$ during autumn storms. The pools were distributed along ca $250 \mathrm{~m}$ of shoreline. The pools were irregularly shaped with the maximum dimension ranging from 2 to $14 \mathrm{~m}$ and maximum depth ranging from 0.21 to $0.75 \mathrm{~m}$. To estimate pool area and volume, parallel transect lines were set at $0.5 \mathrm{~m}$ intervals along the length of each pool to either side of a central line. Length was measured along each transect line and width was measured at $0.5 \mathrm{~m}$ intervals along the central line. This provided a map of the pool perimeter which was then digitized to estimate surface area. Pool depth was measured at $0.3 \mathrm{~m}$ intervals along each of the widthwise transects, subdividing the pool into a grid of $0.5 \times 0.3 \mathrm{~m}$ subunits (units around the perimeter were smaller). Average depth within each subunit was estimated by averaging the depths at each corner, and the volume of each tidepool estimated by summing the subunit volumes. The period of isolation of each pool was measured on 17 dates (June 1990, and at 2 to $6 \mathrm{wk}$ intervals between March 1991 and July 1992) as the period between tidal recession and subsequent tidal input (including spray) and averaged for each pool. The height above chart datum of each pool was measured using a transit level in July 1991 and 1992. Flushing rate of each pool was determined as the percentage decrease in concentration of a fluorescent red dye (Rhodamine $B$, Sigma ${ }^{\circledR}$, St. Louis, MO, USA), added to the pools in known concentration, over the period between low and high tides (i.e. per half a tidal cycle). Decreases in the concentration of the dye were mainly due to tidal exchange, but also due to drainage of the pool, rain, adsorption onto the substratum and uptake by the biota. Changes in dye concentration were measured on a Perkin-Elmer Lambda 3B UV/VIS spectrophotometer. Flushing rate was measured on 9 July 1992, when wave height was between 2 and $3 \mathrm{~m}$ and it was raining lightly, and on 30 August 1993 when wave height was $\sim 1 \mathrm{~m}$ and it was not raining.

For each sampling period, two $60 \mathrm{ml}$ samples of phytoplankton were collected with a polypropylene syringe at each of 2 strata within each pool (at the surface and $<1 \mathrm{~cm}$ above the bottom) and from the surrounding seawater at 2 locations along the shore, immediately below the 2 farthest pools. The phytoplankton samples were placed in a container and the syringe was rinsed into the same container using $20 \mathrm{ml}$ of distilled water. The samples were preserved in Lugol's solution and stored in the dark for subsequent enumeration. Before counting, the phytoplankton samples were inverted 50 times, and subsamples were allowed to settle overnight in $25 \mathrm{ml}$ settling chambers (Lund et al. 1958). Two samples of micrograzers were collected by hand-pumping $5 \mathrm{l}$ of seawater from 0.1 to $0.2 \mathrm{~m}$ above the bottom of each tidepool, at approximately the mid depth of the pools, through a $60 \mu \mathrm{m}$ net. The net was rinsed into a container and the sample fixed with $4 \%$ buffered formaldehyde. Two other samples were collected similarly from the surrounding seawater at the same locations as the phytoplankton samples. Phytoplankton and micrograzers were enumerated using a Leitz Labovert inverted microscope. Phytoplankton was identified according to Cupp (1943), Hendey (1964), Sournia (1986), Ricard (1987) 
and Chrétiennot-Dinet (1990). Micrograzers were identified according to Smith (1964), Brinkhurst et al. (1976), Barnes (1980), and Gardner \& Szabo (1982). Mussel density (Mytilus edulis and/or M. trossulus) was measured in five $0.2 \times 0.2 \mathrm{~m}$ quadrats which were randomly located in each tidepool at each sampling date. Two $60 \mathrm{ml}$ water samples were collected from each pool and at the 2 sea-surface locations for nutrient analysis with an acid-washed ( $1 \mathrm{~N} \mathrm{HCl}$ ) polypropylene syringe. These samples were filtered through $0.80 \mu \mathrm{m}$ Millipore ${ }^{\circledR}$ filters into acid-washed polypropylene containers in the field, and frozen for subsequent analysis (our unpubl. data suggest that freezing over periods of 7 mo had no effect on the concentration of ammonium). Nitrate+nitrite, silicate and phosphate concentrations were measured in these samples using a Technicon AA2 autoanalyzer, and ammonium concentration was determined according to Parsons et al. (1984) on a Jenway 6100 spectrophotometer. The temperature of each pool and the surrounding seawater was measured using a hand-held thermometer; salinity was measured with an Endeco type 102 refractometer; and $\mathrm{pH}$ was measured with a Cole Palmer $\mathrm{pH}$ wand (Model 05830-00).

For statistical analysis, phytoplankton were assigned to 4 taxonomic groups: centric diatoms, pennate diatoms, cryptomonads, and chlorophytes (Table 1). This is a conventional grouping based on successional patterns (e.g. Vanni \& Temte 1990, Venrick 1990, Haigh et al. 1992, Weeks et al. 1993). Micrograzers were grouped as benthic and planktonic according to their functional morphology and mode of feeding. Mussels were grouped into 3 size classes: small $(<1 \mathrm{~cm})$, medium $(1$ to $2 \mathrm{~cm}$ ) and large $(>2 \mathrm{~cm})$ because filtering rate, and therefore effect on phytoplankton abundance, varies largely with mussel size (e.g. Winter 1973, Kemp et al. 1990). For each sampling date, differences in the abundance of phytoplankton for each taxonomic group, as well as differences in the abundance of total phytoplankton, were compared among intertidal zones (mid, high and splash), among pools nested within zones ( 4 per zone), and among strata (surface and bottom of the pools) using 3-factor nested ANOVA. The model used in the ANOVA was:

$$
\begin{aligned}
X_{i j k l} & =\mu+\text { Stratum }_{i}+\text { Zone }_{j}+\text { Stratum } \times \text { Zone }_{l j} \\
& + \text { Pool }\left(\text { Zone }_{k(j)}+\text { Stratum } \times \text { Pool }(\text { Zone })_{i k(j)}+e_{h(j / k)}\right.
\end{aligned}
$$

The effect of the interaction term Stratum $\times$ Pool(Zone) was examined against the residual error, and the effects of the terms Stratum and Stratum $\times$ Zone were examined against the interaction term Stratum $x$ Pool(Zone). In cases where the interaction term Stratum $\times$ Pool(Zone) was significant, the effect of the factor Stratum was examined within each zone. The effect of the factor Zone was examined against the factor
Pool(Zone); if Pool(Zone) was not significant at $\mathrm{p}>$ 0.250 , we pooled the term Pool(Zone) with the residual error and tested the effect of the factor Zone against the pooled error term. The magnitude of the experimental effect of each factor $\left(\omega^{2}\right)$ was calculated for each sampling date, based on models in Howell (1987), using mean square estimates that were defined according to Underwood (1981b).

Differences in densities of micrograzers and mussels, and nutrient concentrations were examined among intertidal zones and among pools nested within zones using 2-factor nested ANOVA, since stratum was not applicable. Differences in temperature, salinity and $\mathrm{pH}$ were examined among zones using single-factor ANOVA. The analyses of variance were based on models given in Winer (1971) and Underwood (1981b). A posteriori multiple comparisons of treatment means were done using Student-Newman-Keuls (SNK) tests. To avoid an increased probability of conducting a type I error due to the large number of analyses of variance, we used the sequential Bonferroni technique to obtain table-wide levels of significance (Rice 1989). In the ANOVA and SNK tests, the null hypothesis was rejected at $p<0.05$.

Forward stepwise multiple regressions (Sokal \& Rohlf 1981, Kleinbaum et al. 1988) were done to examine relationships between the abundance of each phytoplankton group at the surface and at the bottom of the pools with the abundance of planktonic and benthic micrograzers and mussels, the concentration of nutrients (nitrate+nitrite, ammonium, phosphate and silicate), the physical and chemical characteristics of the pools (temperature, salinity, pH, height above chart datum, volume and flushing rate) and the macroalgal cover in the pools as given in Metaxas et al. (1994). Regressions were carried out for the entire sampling period. The $\alpha$-to-add value was 0.150

For all statistical analyses, variables were $\ln (x+1)$ transformed to successfully remove heterogeneity of variance when detected using Cochran's test, or nonnormality when detected in residual plots. All analyses were carried out using SYSTAT versions 5.1 and 5.2 (Wilkinson 1989) on a Macintosh SE 30 computer.

\section{RESULTS}

\section{Spatial patterns of physical and chemical characteristics}

The physical characteristics of the tidepools are given in Table 2. Since phytoplankton can be introduced into the pools through any amount of input of the surrounding seawater (including spray), we assigned replicate pools to intertidal zones according 
Table 1 Frequency of occurrence (number of dates) of the species of phytoplankton that were identified in this study at the sea surface and in 4 tidepools (Pools 1 to 4) sampled in each of 3 zones (mid, high splash) on 14 sampling dates between March 1991 and June 1992

\begin{tabular}{|c|c|c|c|c|c|c|c|c|c|c|c|c|c|}
\hline \multirow[t]{2}{*}{ Taxonomic group } & \multirow{2}{*}{$\begin{array}{c}\text { Sea } \\
\text { surface }\end{array}$} & \multicolumn{4}{|c|}{ Mid pools } & \multicolumn{4}{|c|}{ High pools } & \multicolumn{4}{|c|}{ Splash pools } \\
\hline & & 1 & 2 & 3 & 4 & 1 & 2 & 3 & 4 & 1 & 2 & 3 & 4 \\
\hline \multicolumn{14}{|l|}{ Centric diatoms } \\
\hline Chaetoceros spp. & 6 & 6 & 5 & 4 & 5 & 4 & 4 & 3 & 4 & 5 & 3 & 4 & 5 \\
\hline Coscinodiscus spp. & 2 & 2 & 3 & 1 & 2 & 1 & 1 & 1 & 1 & 2 & 0 & 1 & 2 \\
\hline Detonula confervacea & 1 & 0 & 0 & 0 & 0 & 0 & 0 & 0 & 0 & 0 & 0 & 0 & 0 \\
\hline Leptocylindrus danicus & 2 & 2 & 2 & 2 & 1 & 3 & 3 & 1 & 0 & 2 & 0 & 0 & 2 \\
\hline Melosira nummuloides & 3 & 1 & 1 & 1 & 0 & 1 & 0 & 0 & 0 & 0 & 1 & 0 & 0 \\
\hline Odontella aurita & 2 & 0 & 0 & 0 & 0 & 0 & 0 & 0 & 0 & 0 & 0 & 0 & 0 \\
\hline Rhizosolenia alata & 1 & 2 & 2 & 1 & 0 & 0 & 0 & 0 & 0 & 0 & 0 & 1. & 0 \\
\hline R. delicatula & 4 & 0 & 1 & 0 & 1 & 0 & 1 & 0 & 2 & 1 & 0 & 0 & 1 \\
\hline R. fragilissima & 2 & 2 & 2 & 3 & 1 & 1 & 1 & 1 & 1 & 1 & 0 & 1 & 1 \\
\hline R. setigera & 3 & 1 & 2 & 1 & 1 & 0 & 1 & 0 & 1 & 1 & 0 & 0 & 0 \\
\hline R. styliformis & 1 & 1 & 1 & 0 & 0 & 0 & 0 & 0 & 0 & 0 & 0 & 0 & 0 \\
\hline Skeletonema costatum & 10 & 6 & 7 & 7 & 7 & 6 & 6 & 8 & 5 & 7 & 8 & 6 & 5 \\
\hline Thalassiosira gravida & 1 & 0 & 0 & 0 & 0 & 0 & 0 & 0 & 0 & 0 & 1 & 0 & 0 \\
\hline T hyalina & 2 & 2 & 1 & 2 & 1 & 0 & 0 & 0 & 0 & 0 & 0 & 0 & 0 \\
\hline T. nordenskioldii & 3 & 3 & 3 & 3 & 1 & 0 & 1 & 2 & 2 & 3 & 2 & 4 & 3 \\
\hline \multicolumn{14}{|l|}{ Pennate diatoms } \\
\hline Amphiproraspp. & 3 & 5 & 6 & 8 & 7 & 6 & 8 & 6 & 6 & 4 & 8 & 5 & 6 \\
\hline Amphora spp. & 2 & 1 & 2 & 2 & 2 & 1 & 2 & 4 & 3 & 2 & 5 & 3 & 2 \\
\hline Campylosira cymbelliformts & 0 & 0 & 1 & 0 & 0 & 0 & 0 & 0 & 0 & 0 & 0 & 0 & 0 \\
\hline Cylindrotheca closterum & 9 & 11 & 11 & 13 & 11 & 10 & 12 & 8 & 8 & 3 & 8 & 7 & 4 \\
\hline Fragilaria crotonensis & 5 & 6 & 3 & 4 & 2 & 1 & 4 & 3 & 4 & 3 & 2 & 1 & 2 \\
\hline Grammatophora angulosa & 5 & 5 & 2 & 2 & 2 & 2 & 0 & 3 & 2 & 0 & 0 & 0 & 1 \\
\hline Gyrosigma sp. & 0 & 1 & 0 & 0 & 1 & 0 & 0 & 0 & 0 & 0 & 0 & 0 & 0 \\
\hline Licmophora gracilis & 4 & 5 & 5 & 6 & 5 & 6 & 4 & 2 & 5 & 2 & 3 & 5 & 3 \\
\hline L. juergensii & 10 & 13 & 11 & 12 & 11 & 10 & 10 & 10 & 9 & 7 & 9 & 13 & 7 \\
\hline Navicula spp. & 11 & 13 & 12 & 11 & 10 & 6 & 7 & 9 & 7 & 5 & 8 & 5 & 5 \\
\hline Nitzschia delicatissuma & 5 & 1 & 4 & 3 & 2 & 3 & 5 & 1 & 2 & 1 & 5 & 3 & 2 \\
\hline N. longissima & 7 & 2 & 3 & 4 & 4 & 2 & 1 & 6 & 3 & 3 & 4 & 4 & 1 \\
\hline$N$ seriata & 7 & 4 & 5 & 3 & 4 & 1 & 4 & 3 & 3 & 5 & 2 & 3 & 3 \\
\hline Nitzschia spp. & 11 & 14 & 13 & 14 & 13 & 12 & 13 & 11 & 11 & 9 & 11 & 10 & 10 \\
\hline Plagiogramma stauroforum & 2 & 5 & 3 & 4 & 3 & 3 & 4 & 5 & 4 & 2 & 2 & 2 & 3 \\
\hline Striatella unipunctata & 1 & 2 & 2 & 2 & 2 & 1 & 1 & 0 & 0 & 0 & 0 & 0 & 0 \\
\hline Surirella spp. & 0 & 2 & 4 & 4 & 5 & 3 & 3 & 1 & 4 & 3 & 3 & 4 & 4 \\
\hline Thalassionema nitzschiordes & 0 & 1 & 2 & 0 & 1 & 2 & 1 & 3 & 0 & 1 & 1 & 1 & 1 \\
\hline Thalassiothrix frauenfeldir & 4 & 5 & 1 & 3 & 3 & 4 & 1 & 2 & 1 & 1 & 2 & 2 & 3 \\
\hline Unidentified pennates & 13 & 13 & 1.3 & 11 & 13 & 11 & 10 & 9 & 10 & 6 & 12 & 11 & 8 \\
\hline \multicolumn{14}{|l|}{ Cryptomonads } \\
\hline Cryptomonas spp. & 11 & 12 & 12 & 14 & 14 & 14 & 14 & 14 & 14 & 14 & 14 & 14 & 14 \\
\hline \multicolumn{14}{|l|}{ Chlorophytes } \\
\hline Dunaliella tertiolecta & 3 & 5 & 5 & 5 & 5 & 5 & 5 & 5 & 5 & 6 & 5 & 5 & 6 \\
\hline \multicolumn{14}{|l|}{ Euglenoids } \\
\hline Euglena spp. & 0 & 1 & 1 & 0 & 0 & 0 & 0 & 3 & 0 & 0 & 0 & 0 & 0 \\
\hline
\end{tabular}

to the period of isolation from tidal input. Pools with average periods of isolation ranging from 3 to $8 \mathrm{~h}$ were assigned to the mid zone, those with periods ranging from 10 to $12 \mathrm{~h}$ were assigned to the high zone, and pools that usually did not receive any input over a cycle, except during storms, were assigned to the splash zone.

Mean temperature at the sea surface and in the tidepools increased from a low around March to a peak in
July 1991 (Fig. 1). It remained high throughout summer and early autumn but decreased by November 1991. The increase between March and June 1992 was similar to that of the previous year. Mid pools were significantly (SNK test) colder than high and splash pools in June $1992\left(F_{2,9}=11.65, p<0.001\right)$. Splash pools were significantly colder than mid and high pools in October $1991\left(F_{2,9}=28.77, \mathrm{p}<0.001\right)$. Mean salinity remained relatively constant at the sea surface and in the mid 
Table 2. Physical characteristics of 4 tidepools (Pools 1 to 4 ) located in each of 3 intertidal zones (mid, high and splash), at Cranberry Cove, Nova Scotia, Canada. CD: chart datum; -: no recorded input during 12 h tidal cycle; SD: standard deviation

\begin{tabular}{|c|c|c|c|c|c|c|c|}
\hline \multirow[t]{2}{*}{ Intertidal zone } & \multirow[t]{2}{*}{$\begin{array}{l}\text { Surface } \\
\text { area }\left(\mathrm{m}^{2}\right)\end{array}$} & \multirow[t]{2}{*}{$\begin{array}{l}\text { Maximum } \\
\text { depth (m) }\end{array}$} & \multirow[t]{2}{*}{$\begin{array}{l}\text { Volume } \\
\qquad\left(\mathrm{m}^{3}\right)\end{array}$} & \multirow[t]{2}{*}{$\begin{array}{l}\text { Isolation } \\
\text { period (h) }\end{array}$} & \multirow[t]{2}{*}{$\begin{array}{l}\text { Height above } \\
\text { CD (m) }\end{array}$} & \multicolumn{2}{|c|}{$\begin{array}{c}\text { Flushing rate } \\
\text { per } 1 / 2 \text { tidal cycle }(\%)\end{array}$} \\
\hline & & & & & & July 1992 & August 1993 \\
\hline \multicolumn{8}{|l|}{ Mid zone } \\
\hline Pool 1 & 3.20 & 0.15 & 0.19 & 3 & 1.2 & 100 & 100 \\
\hline Pool 2 & 10.91 & 0.45 & 2.03 & 5 & 1.4 & 100 & 100 \\
\hline Pool 3 & 14.36 & 0.36 & 1.81 & 7 & 2.3 & 75 & 94 \\
\hline Pool 4 & 8.94 & 0.46 & 2.27 & 8 & 1.2 & 37 & 48 \\
\hline Mean $\pm S D$ & $9.35 \pm 4.67$ & $0.36 \pm 0.14$ & $1.58 \pm 0.94$ & $6 \pm 2$ & $1.5 \pm 0.5$ & $78 \pm 30$ & $86 \pm 25$ \\
\hline \multicolumn{8}{|l|}{ High zone } \\
\hline Pool 1 & 10.04 & 0.19 & 0.92 & 12 & 3.0 & 15 & 21 \\
\hline Pool 2 & 1.5 .75 & 0.27 & 1.49 & 11 & 2.5 & 66 & 99 \\
\hline Pool 3 & 24.23 & 0.64 & 7.28 & 12 & 2.6 & 23 & 0 \\
\hline Pool 4 & 11.84 & 0.13 & 0.68 & 10 & 2.9 & 40 & 8 \\
\hline Mean $\pm \mathrm{SD}$ & $15.47 \pm 6.31$ & $0.31 \pm 0.23$ & $2.59 \pm 3.14$ & $11 \pm 1$ & $2.8 \pm 0.2$ & $36 \pm 23$ & $32 \pm 46$ \\
\hline \multicolumn{8}{|l|}{ Splash zone } \\
\hline Pool 1 & 0.68 & 0.13 & 0.05 & - & 2.8 & 0 & 11. \\
\hline Pool 2 & 8.85 & 0.31 & 1.15 & - & 3.4 & 37 & 4 \\
\hline Pool 3 & 7.47 & 0.32 & 0.71 & - & 3.9 & 36 & 7 \\
\hline Pool 4 & 3.94 & 0.43 & 0.94 & - & 4.5 & 52 & 0 \\
\hline Mean $\pm S D$ & $5.24 \pm 3.67$ & $0.30 \pm 0.12$ & $0.71 \pm 0.48$ & - & $3.7 \pm 0.7$ & $31 \pm 22$ & $6 \pm 5$ \\
\hline
\end{tabular}
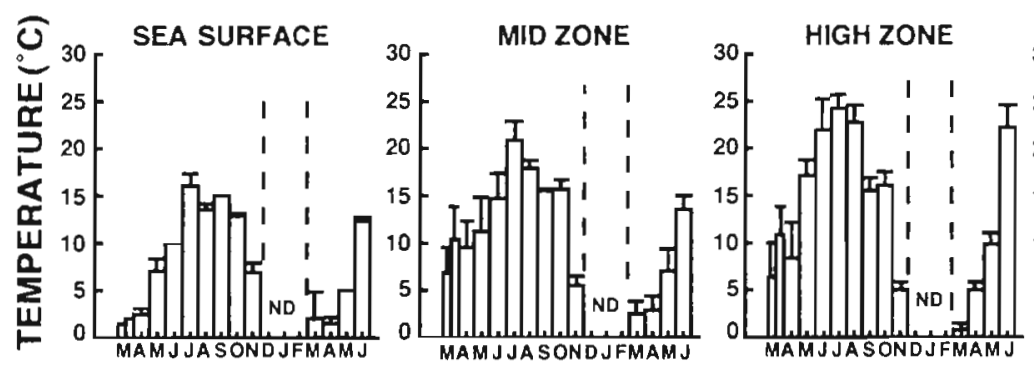

SPLASH ZONE
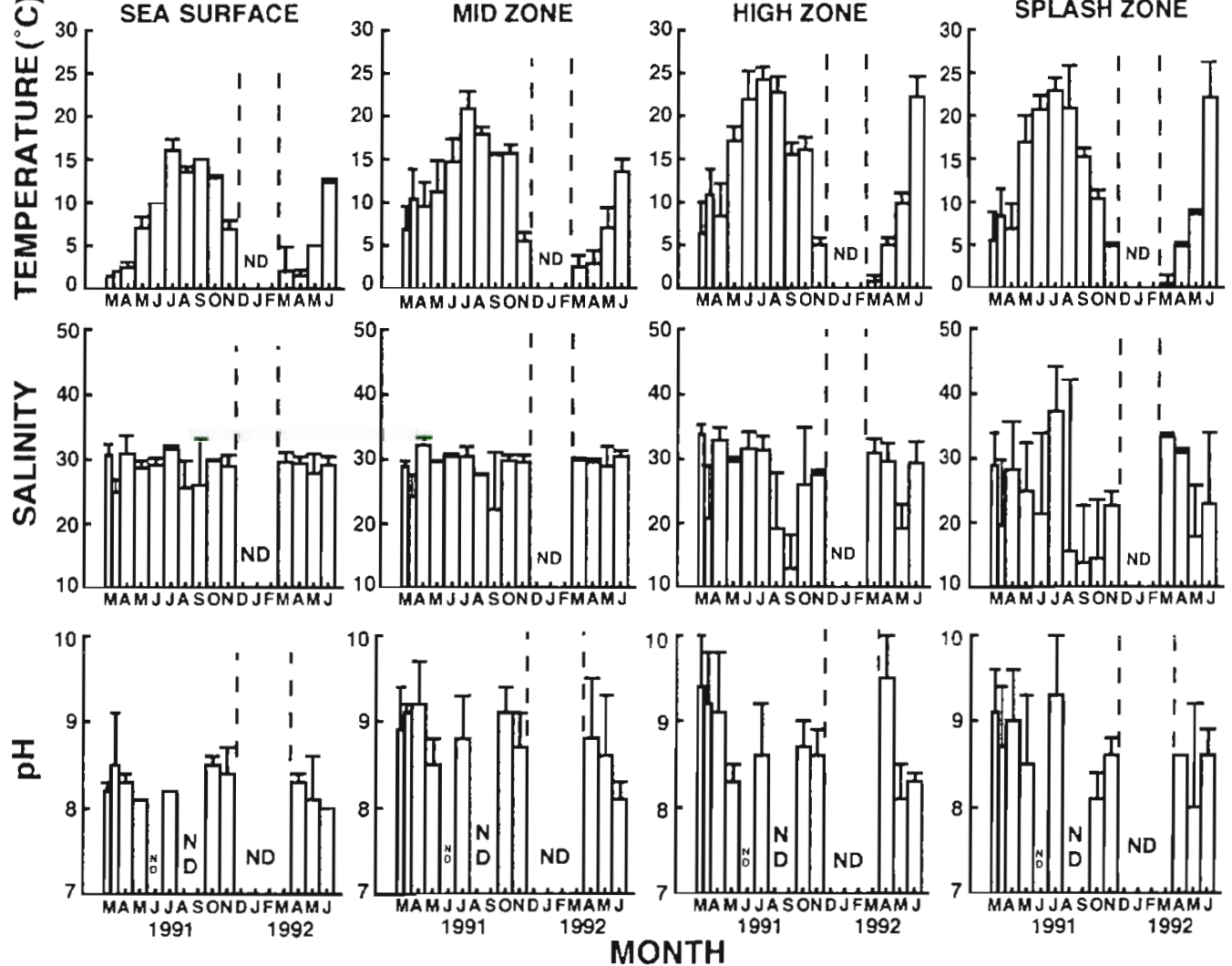

MONTH

Fig. 1. Mean temperature, salinity and $\mathrm{pH}( \pm \mathrm{SD})$ at the sea surface $(\mathrm{n}=2)$ and in tidepools $(\mathrm{n}=4)$ in 3 intertidal zones (mid, high, splash) at Cranberry Cove, Nova Scotia, Canada, sampled at approximately monthly intervals between March and November 1991 and March and June 1992 (twice during the bloom in March 1.991). ND: no data. 
pools over the 16 mo study, but was reduced significantly due to rain in splash pools in November 1991 $\left(F_{2,9}=22.19, \mathrm{p}<0.001\right)$ (Fig. 1$)$. Mean pH at the sea surface did not fluctuate over the 16 mo, but was greater and more variable in the pools (Fig. 1); $\mathrm{pH}$ did not vary significantly among zones on any sampling date.

\section{Spatial patterns of phytoplankton abundance}

The abundance of total phytoplankton was greatest in the surrounding seawater in March 1991 and May 1992 due to spring blooms, and in October 1991 due to an autumn bloom (Fig. 2). Similar patterns of abundance were observed for centric diatoms, the dominant phytoplankton group during the blooms (Fig. 3). The abundance of pennate diatoms was greatest after the spring bloom in 1991 and around the bloom in 1992 (Fig. 4). Cryptomonads and chlorophytes were less abundant than diatoms: their mean abundance never exceeded $10^{4}$ cells $1^{-1}$ at the sea surface (Figs. 5 \& 6).

In tidepools, the abundance of total phytoplankton and of individual taxonomic groups varied significantly between strata on a number of sampling dates. Total phytoplankton was more abundant at the bottom than at the surface of pools in spring (all pools: 17 March and April 1991, April 1992; splash pools: May 1992), and in autumn (all pools: October 1991) (Fig 2, Table 3). Centric diatoms were more abundant at the bottom than at the surface of all pools in October 1991 (Fig. 3, Table 4). Pennate diatoms were more abundant at the bottom than at the surface of pools in
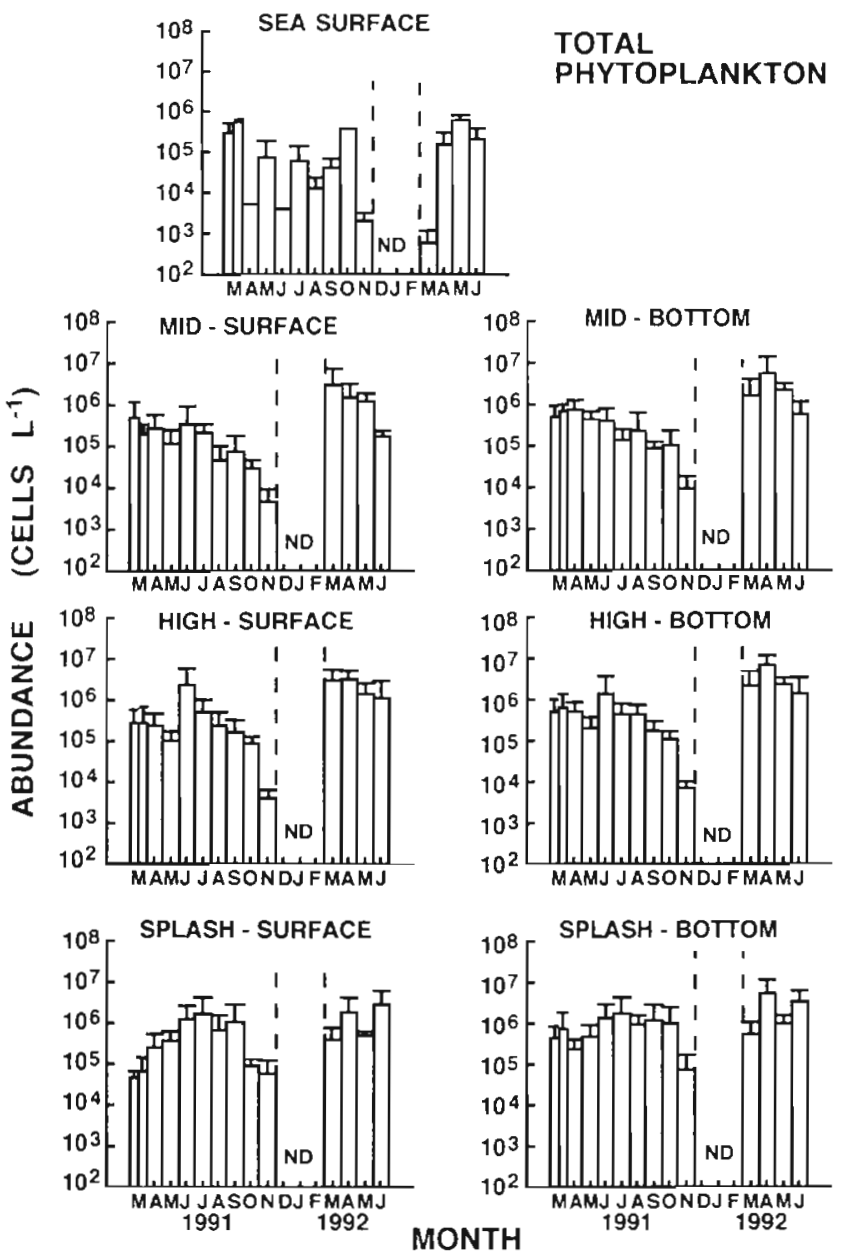

Fig. 2. Mean abundance of total phytoplankton $( \pm S D)$ at the sea surface $(n=2)$ and at the surface and bottom of tidepools $(\mathrm{n}=4)$ in 3 intertidal zones (mid, high, splash) at Cranberry Cove, Nova Scotia, sampled at approximately monthly intervals between March and November 1991 and March and June 1992 (twice during the bloom in March 1991). ND: no data
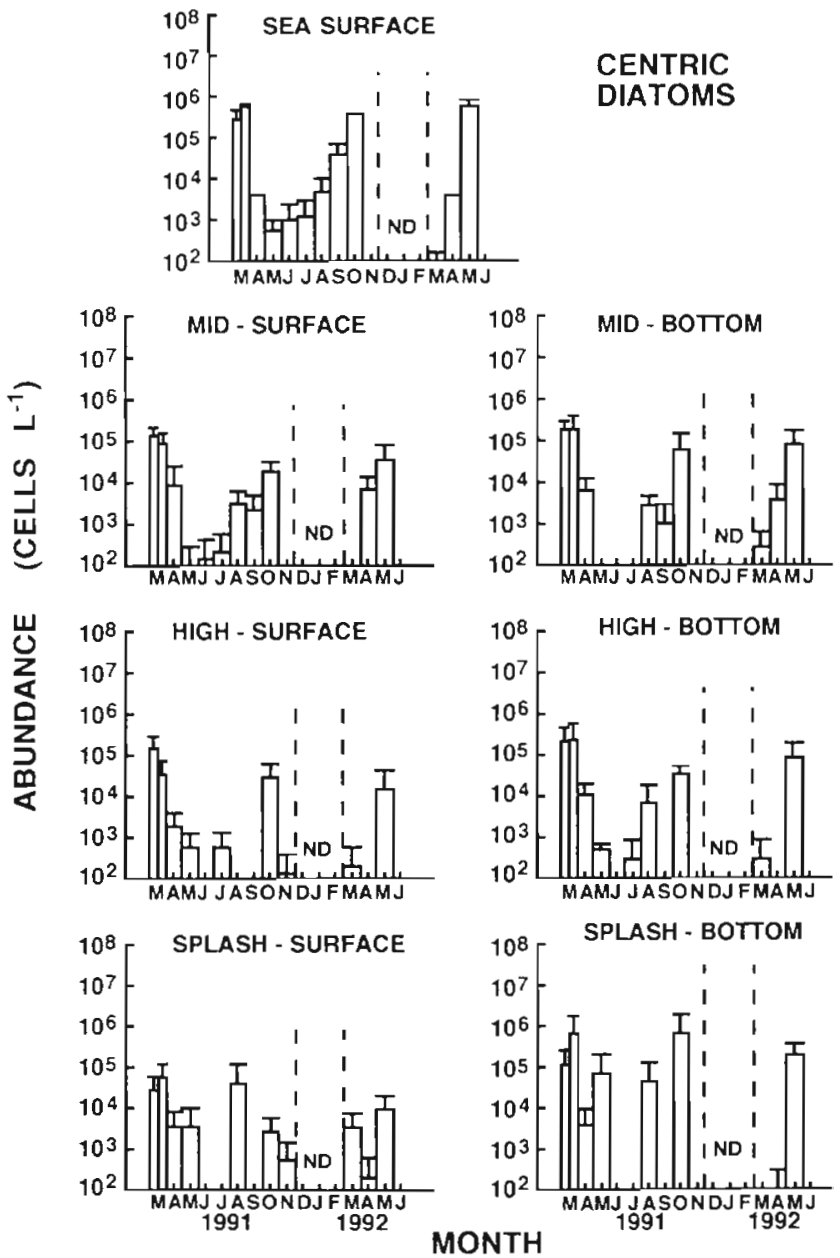

SPLASH - BOTTOM

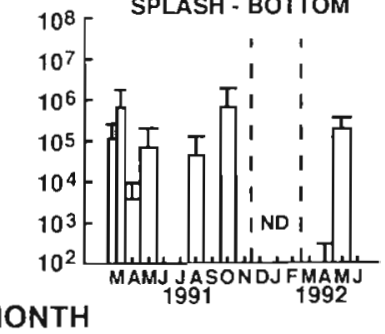

Fig. 3, Mean abundance of centric diatoms $( \pm S D)$ at the sea surface $(n=2)$ and at the surface and bottom of tidepoois ( $n=$ 4) in 3 intertidal zones (mid, high, splash) at Cranberry Cove, Nova Scotia, sampled at approximately monthly intervals between March and November 1991 and March and June 1992 (twice during the bloom in March 1991). ND: no data 
spring (all pools: 17 March and April 1991, April and May 1992), although they were more abundant at the surface than at the bottom of all pools on 1 date (27 March 1991) (Fig. 4, Table 5). Cryptomonads were more abundant at the surface than at the bottom of all pools on 27 March 1991 (Fig. 5, Table 6). Chlorophytes were more abundant at the bottom than at the surface of all pools on 2 out of the 7 sampling dates (April and June 1992) (Fig. 6, Table 7).

The abundance of total phytoplankton and the individual taxonomic groups did not vary significantly among intertidal zones on any sampling date (Figs. 2 to 6, Table 3 to 7). However, the abundance of total phytoplankton and all taxonomic groups was highly variable among pools within zones throughout the study. The abundance of total phytoplankton varied significantly among pools within zones on all sampling dates (mid pools: all dates except May and July to September 1991, May 1992; high pools: all dates except August and November 1991; splash pools: all dates except May 1992) (Fig. 2, Table 3) The abundance of centric diatoms varied significantly among pools within zones on 6 out of 11 dates (mid pools: 17 and 27 March 1991, April 1992; high pools: 17 and 27 March and October 1991, May and June 1992; splash pools: 17 and 27 Narch, May and October 1991, March 1992) (Fig. 3, Table 4). The abundance of pennate diatoms varied significantly among pools on 7 out of 14 dates (mid pools: 17 and 27 March 1991, March to May 1992; high pools: 17 March, May and July 1991, April and May 1992; splash pools: 17 March to May 1991, March to May 1992) (Fig. 4, Table 5). The abundance of cryp-
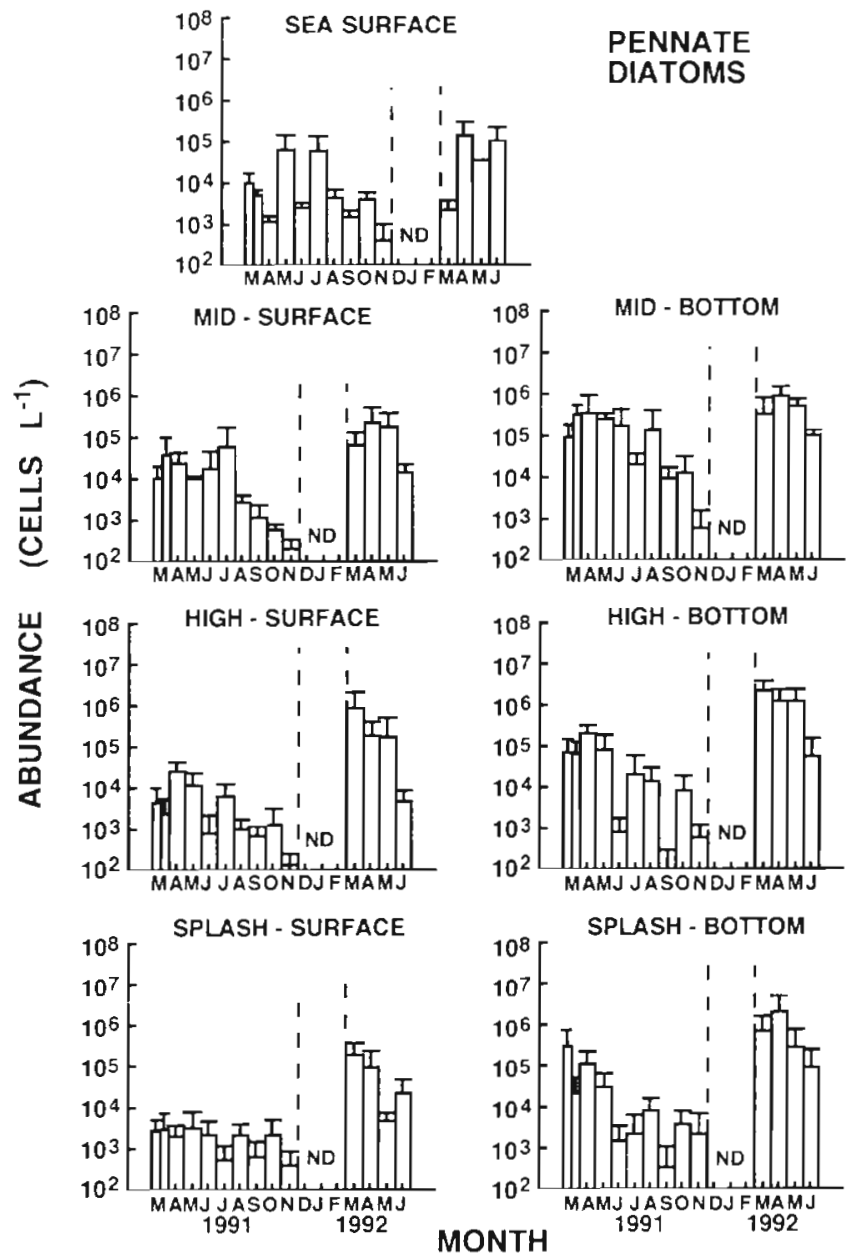

Fig. 4. Mean abundance of pennate diatoms ( $\pm \mathrm{SD}$ ) at the sea surface $(n=2)$ and at the surface and bottom of tidepools ( $n=$ 4) in 3 intertidal zones (mid, high, splash) at Cranberry Cove, Nova Scotia, sampled at approximately monthly intervals between March and November 1991 and March and June 1992 (twice during the bloom in March 1991). ND: no data
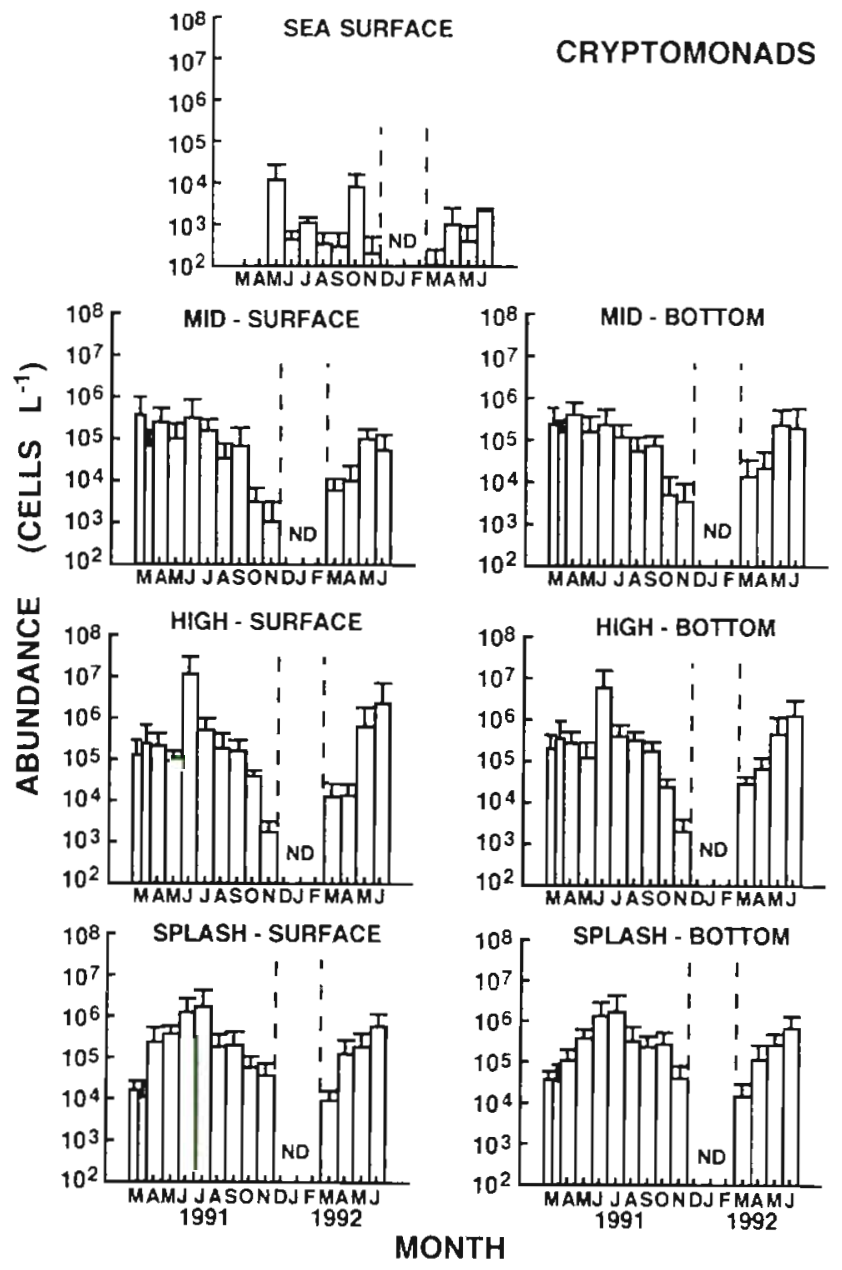

Fig. 5. Mean abundance of cryptomonads ( \pm SD) at the sed surface $(n=2)$ and at the surface and bottom of tidepools ( $n=$ 4) in 3 intertidal zones (mid, high, splash) at Cranberry Cove, Nova Scotia, sampled at approximately monthly intervals between March and November 1991 and March and June 1992 (twice during the bloom in March 1991). ND: no data 
tomonads varied significantly among pools on 13 out of 14 dates (mid pools: 17 March to June, August, October and November 1991, May and June 1992; high pools: 17 March to September and November 1991, April to June 1992; splash pools: on all dates except March 1992) (Fig 5, Table 6). The abundance of chlorophytes varied significantly among pools within zones on all dates (mid pools: August, October and November 1991, March to May 1992; high pools: August and October 1991, March to June 1992; splash pools: August, September and November 1991, March, April and June 1992) (Fig. 6, Table 7). Although not statistically analyzed, we observed pulses in the abundance of a euglenoid on 2 dates (June 1991 and June 1992; ca $1 \times 10^{6}$ and $3.5 \times 10^{5}$ cells $1^{-1}$, respectively) but only in 1 high pool (Table 1 ).

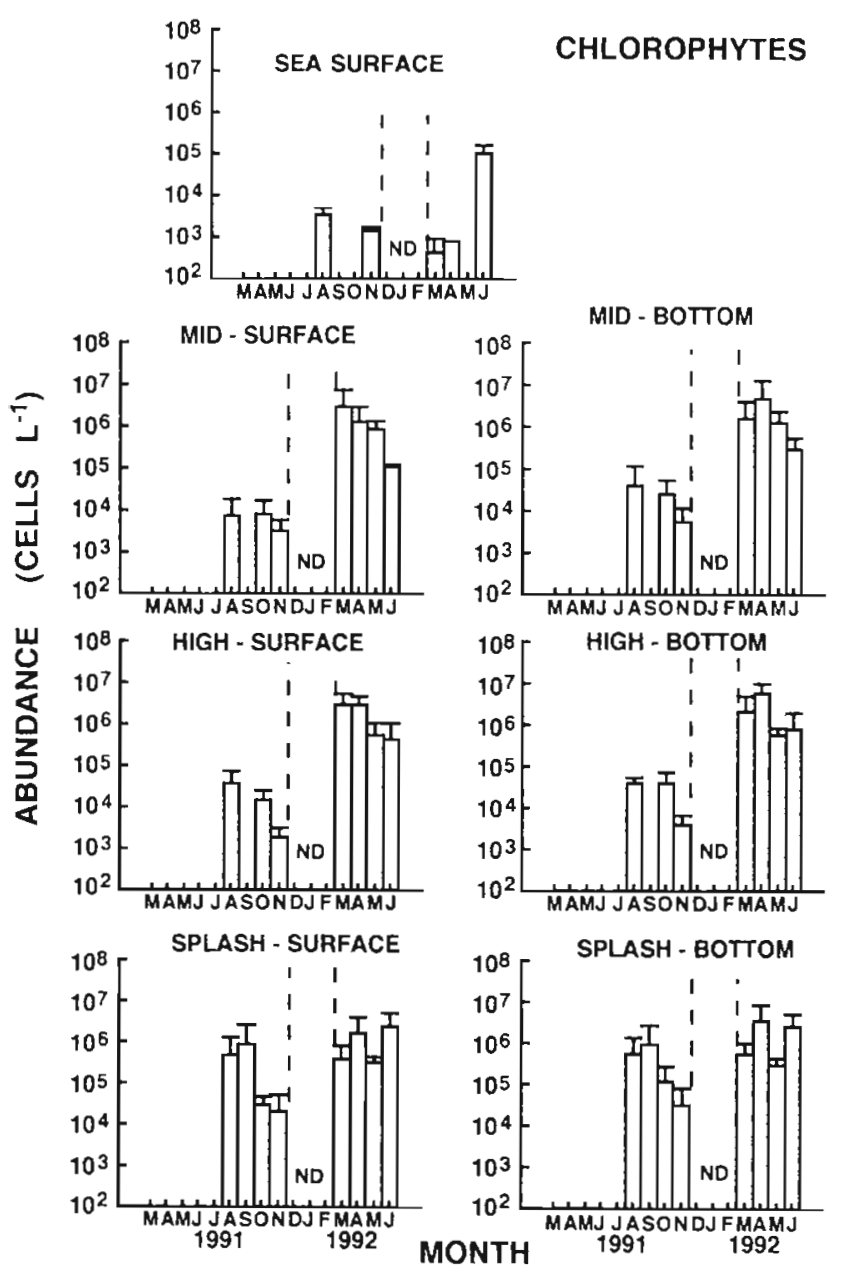

Fig. 6. Mean abundance of chlorophytes $( \pm S D)$ at the sea surface $(n=2)$ and at the surface and bottom of tidepools ( $\mathrm{n}=$ 4) in 3 intertidal zones (mid, high, splash) at Cranberry Cove, Nova Scotia, sampled at approximately monthly intervals between March and November 1991 and March and June 1992 (twice during the bloom in March 1991). ND: no data

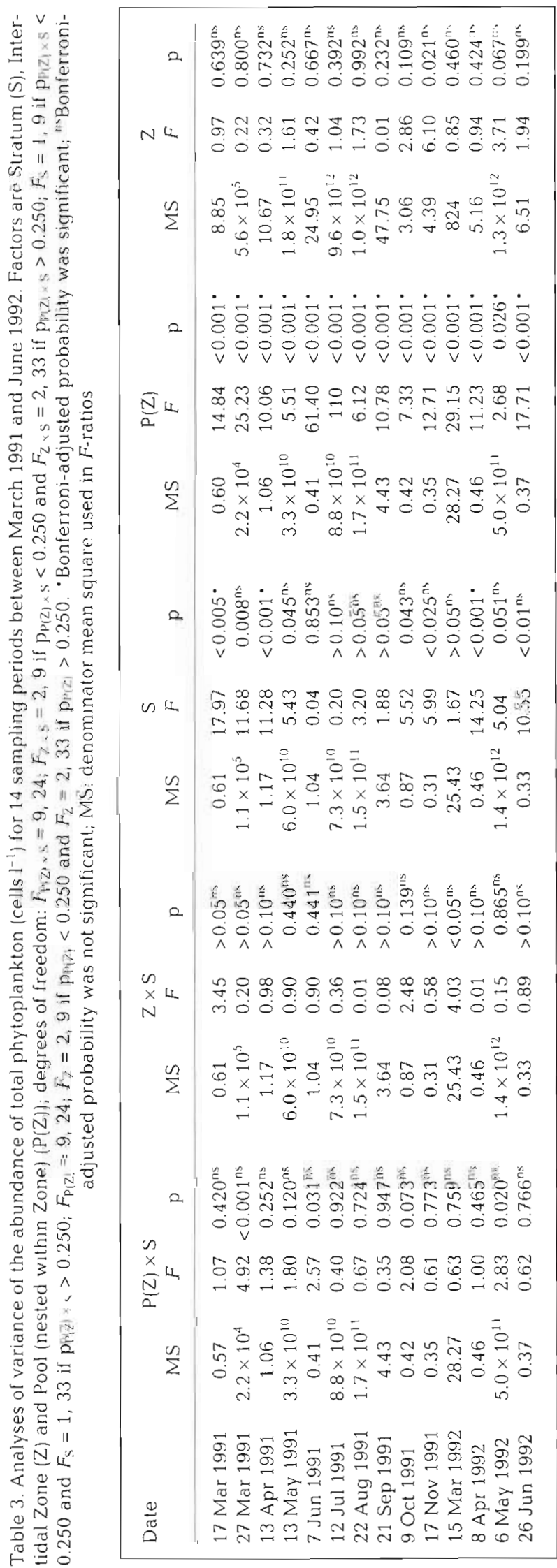




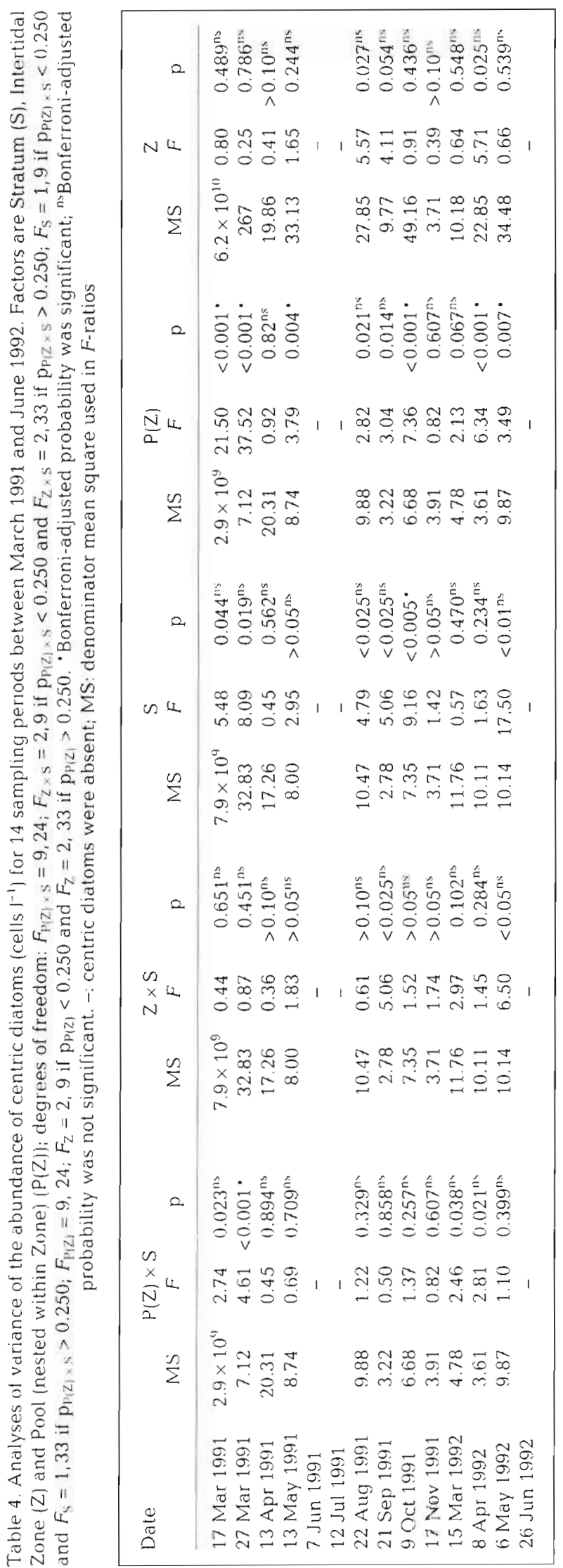

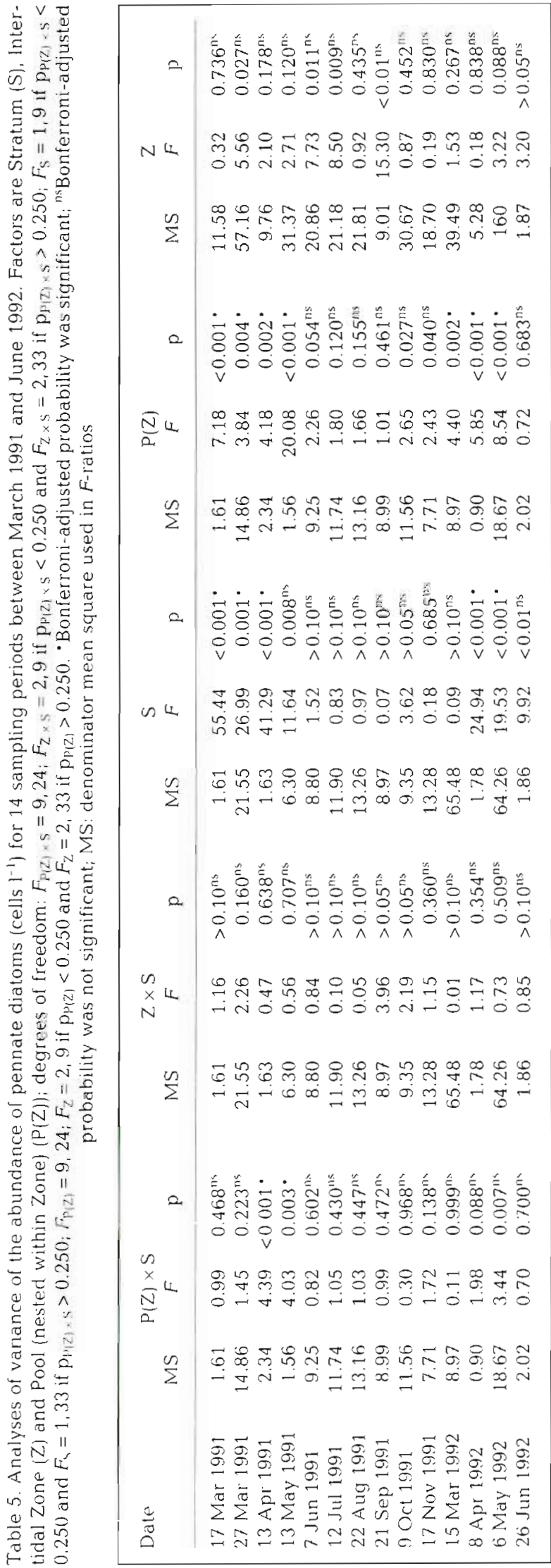




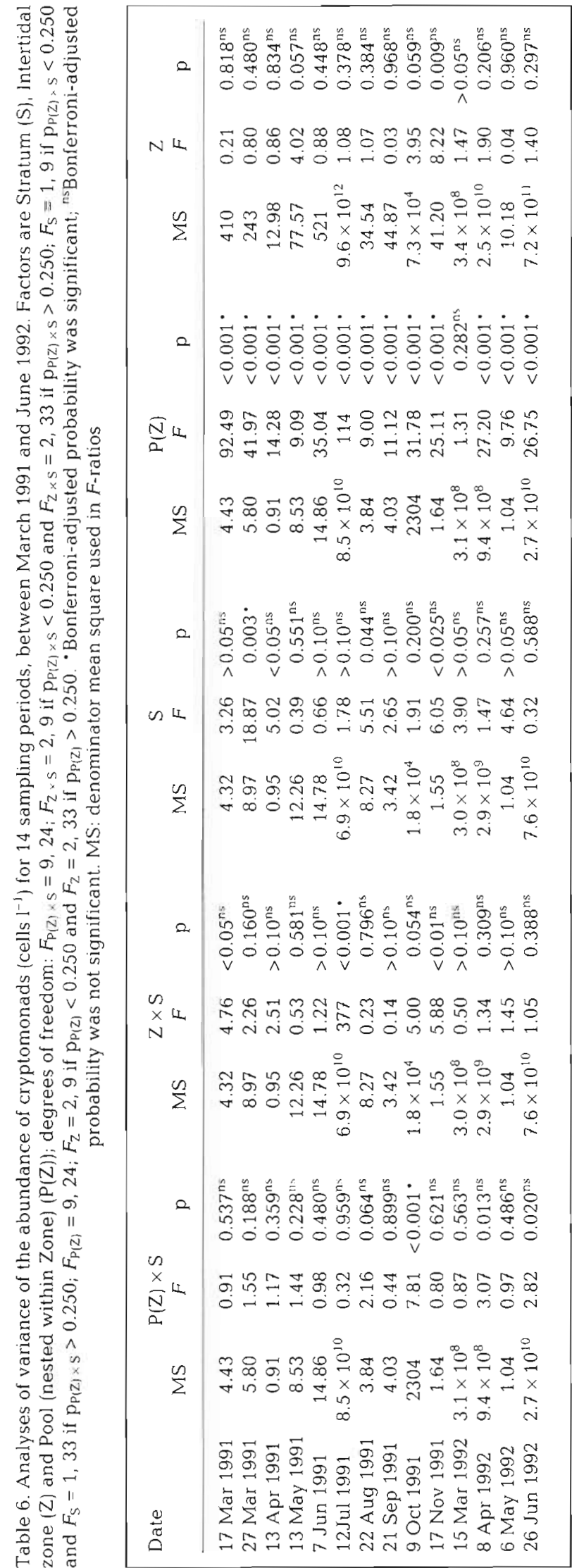

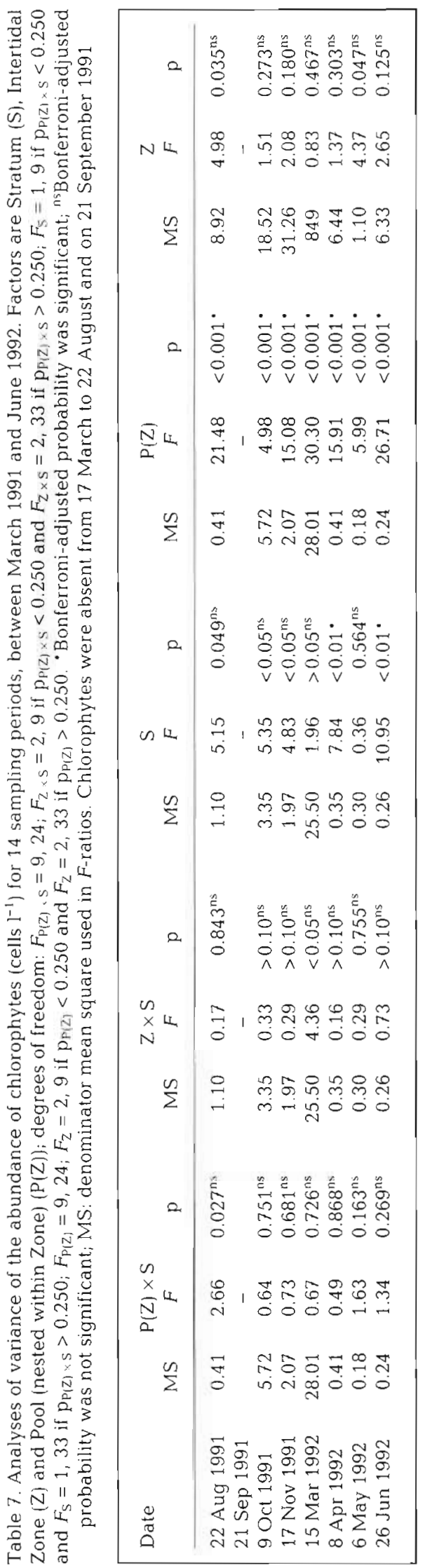


The magnitude of the effect that each source of spatial variability had on phytoplankton abundance varied among groups but was relatively consistent among dates for most groups (Fig. 7). Variability in abundance of total phytoplankton, cryptomonads and chlorophytes was explained largely by variability among pools within zones, whereas variability in abundance of centric and pennate diatoms was explained to similar extents by variability among zones and between strata, as well as among pools within zones. Variability among pools within intertidal zones was $13-96 \%$ (on all dates) of total variability for total phytoplankton; for cryptomonads it was 6-96\% (on all dates); for chlorophytes it was $33-86 \%$ (on all dates); for centric diatoms it was $11-69 \%$ (on 9 out of 11 dates); and for pennate diatoms it was $10-42 \%$ (on 12 of 14 dates) of total variability. Variability
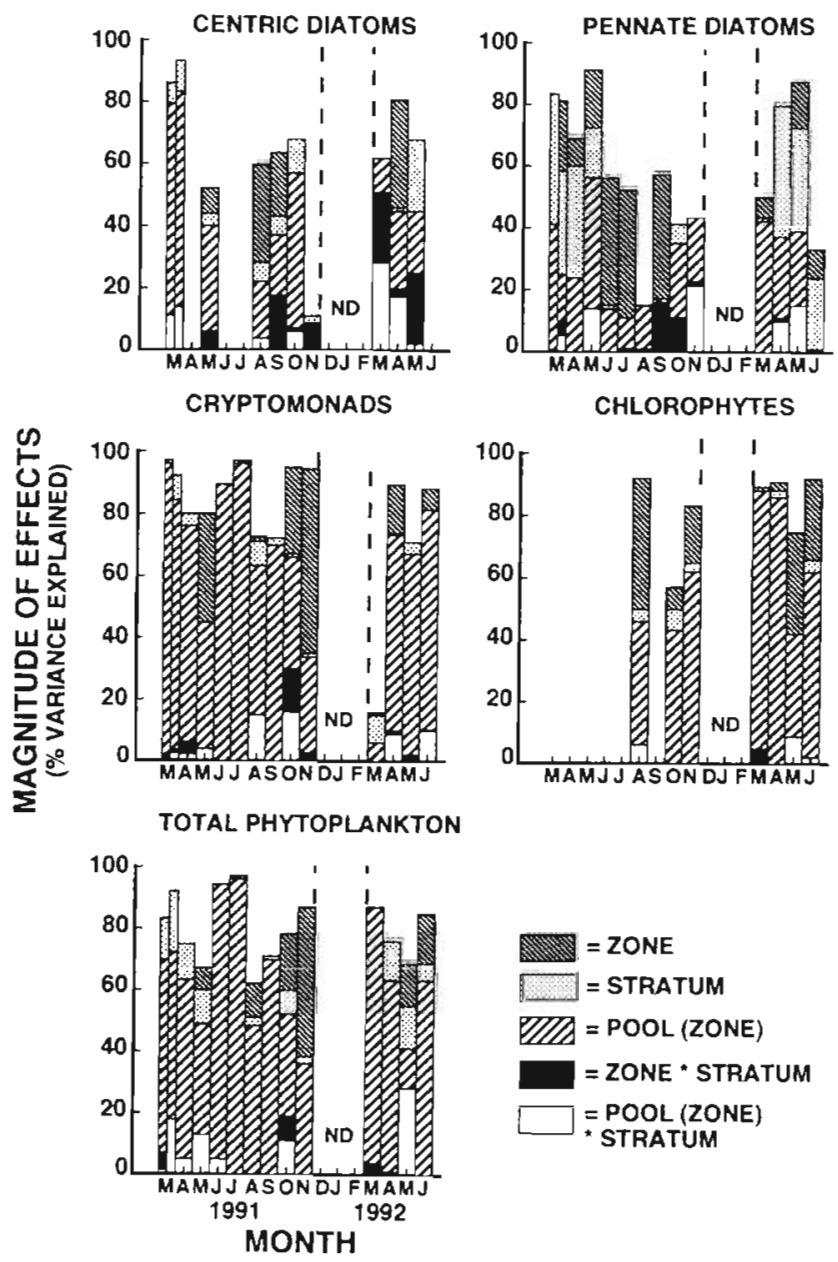

Fig. 7. Magnitude of effects of each factor [Zone, Stratum, PooliZonel], as well as of the interaction terms [Zone $\times$ Stratum, Pool(Zone) $\times$ Stratum|, in the analyses of variance of the abundance of total phytoplankton and of each phytoplankton group for each sampling date. ND: no data among zones was $1-49 \%$ (on 7 of 14 dates) of total variability for total phytoplankton; for cryptomonads it was $1-59 \%$ (on 7 of 14 dates); for chlorophytes it was $3-42 \%$ (on 6 of 7 dates); for centric diatoms it was $8-35 \%$ (on 4 of 11 dates); and for pennate diatoms it was $7-23 \%$ (on 9 of 14 dates) of total variability. Variability between strata was $1-20 \%$ (on 11 of 14 dates) of total variability for total phytoplankton; for cryptomonads it was $1-10 \%$ (on 10 of 14 dates); for chlorophytes it was $1-7 \%$ (on 5 of 7 dates); for centric diatoms it was $1-23 \%$ (on 9 of 11 dates); and for pennate diatoms it was $1-42 \%$ (on 10 of 14 dates) of total variability. The interaction term Zone $\times$ Stratum accounted for $<23 \%$ and the interaction term Pool (Zone) $\times$ Stratum accounted for $<28 \%$ of the variability in the abundance of all phytoplankton groups on all sampling dates. The amount of residual variability in abundance varied among phytoplankton groups and among sampling dates: for total phytoplankton, residual variability was $4-37 \%$ of total variability; for centric diatoms it was $8-40 \%$, except in April and November 1991 when it was $100 \%$ and $89 \%$, respectively; for pennate diatoms it was $9-67 \%$, except in August 1991, when it was $85 \%$; for cryptomonads it was 3-29\%, except in March 1992. when it was $72 \%$; and for chlorophytes it. was $8-43 \%$ of total variability.

\section{Spatial patterns of grazer abundance}

The major groups of planktonic micrograzers were calanoid copepodites and nauplii (the genera Acartia, Calanus, Paracalanus, Pseudocalanus and Temora at the sea surface and in mid pools, and Eurytemora affinis in splash pools), marine cladocerans (Podon polyphemoides and Evadne nordmanil) and marine rotifers (the genera Brachionus and Synchaeta) (for a more detailed description see Metaxas \& Scheibling 1994a). The abundance of planktonic micrograzers did not vary significantly among zones on any sampling date but varied significantly among pools within zones on 4 of 14 sampling dates (June to August 1991, June 1992) (Fig. 8. Table 8).

The major groups of benthic micrograzers included harpacticoid copepodites and nauplii (families Harpacticidae, Tisbidae, Thalestridae and Diosaccidac), foraminiferans and nematodes (see Metaxas \& Scheibling 1994a). The abundance of benthic micrograzers did not vary significantly among zones on any sampling date but varied significantly among pools within zones in June 1991 (Fig. 8, Table 8).

Mussels Mytilus edulis and/or $M$. trossulus were abundant in mid and high pools throughout the sampling season, but small mussels were never found in 
some high and splash pools (Fig. 9, see also Metaxas et al. 1994). The abundance of small mussels was greater in mid than high and splash pools on 1 sampling date (September 1991), but varied significantly (SNK test) among pools within zones on 5 of 14 dates (June to August 1991, May and June 1992) (Table 9). The abundance of medium-sized mussels was greater in mid than in high and/or splash pools on 1 sampling date (May 1992), and varied significantly among pools within zones on all sampling dates, except August 1991 (Table 9). The abundance of large mussels did not vary significantly among intertidal zones on any sampling date, but varied significantly among pools within zones on all sampling dates except May 1992 (Table 9).

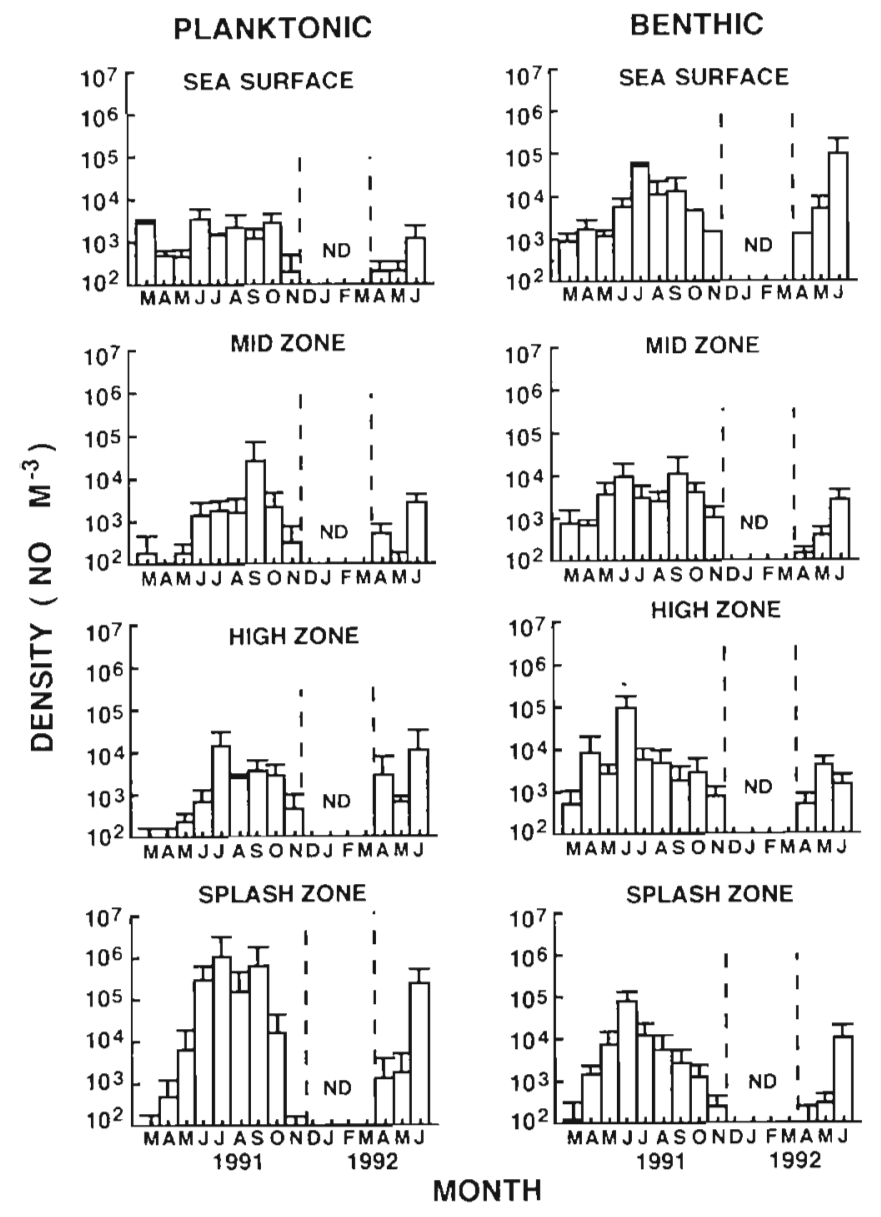

Fig. 8. Mean density of planktonic and benthic micrograzers $( \pm S D)$ at the sea surface $(n=2)$ and at the surface and bottom of tidepools $(n=4)$ in 3 intertidal zones (mid, high, splash) at Cranberry Cove, Nova Scotia, sampled at approximately monthly intervals between March and November 1991 and April and June 1992. ND: no data

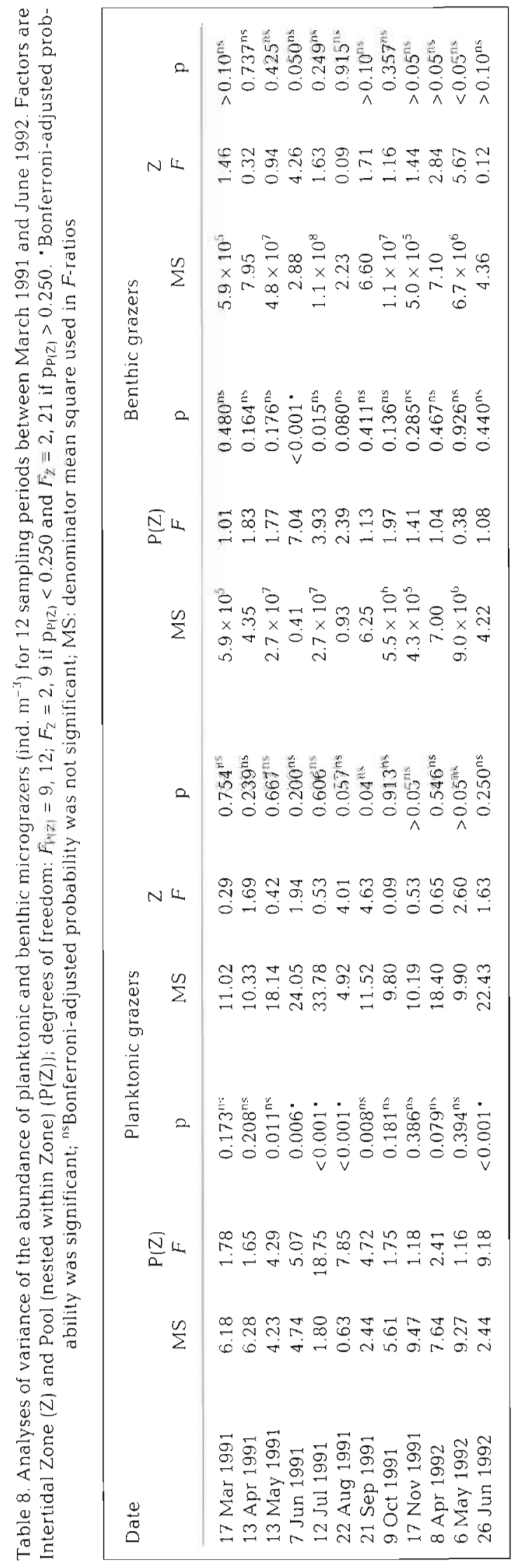




\section{Spatial patterns of nutrient concentration}

The concentrations of macronutrients varied little among zones but was variable throughout the sampling season among pools within zones (Figs. $10 \& 11$ ). The concentration of nitrate+nitrite, ammonium and silicate did not vary significantly among zones on any sampling date but varied significantly among pools within zones on 6 of 14,4 of 9 and 3 of 14 dates, respectively (nitrate+nitrite: 17 and 27 March, April and August 1991, May and June 1992; ammonium: May, July and September 1991, April 1992; phosphate: 27 March, April and September 1991) (Table 10). The concentration of silicate was significantly larger in mid than in high and/or splash pools in November 1991, and varied significantly among pools on 10 of 14 dates (March to May, July to September 1991, March to June 1992).

\section{Relationships of phytoplankton abundance with biotic and abiotic factors}

The abundance of phytoplankton varied significantly with most of the biotic and some of the abiotic

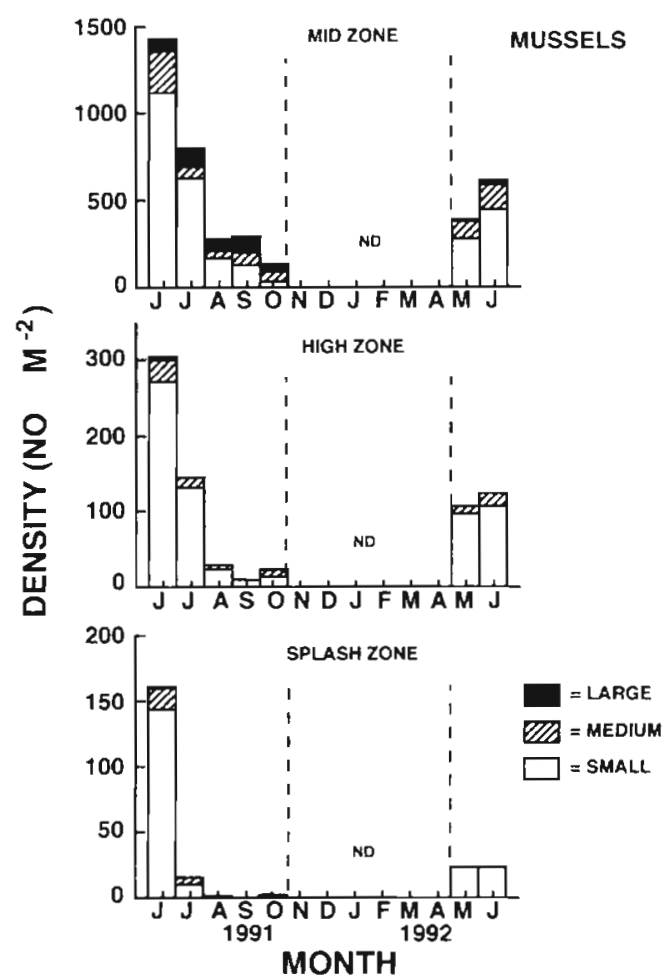

Fig. 9. Mean density of small, medium and large mussels in tidepools in 3 intertidal zones (mid, high, splash) at Cranberry Cove, Nova Scotia, sampled at approximately monthly intervals between June and October 1991 and in May and June 1992. ND: no data

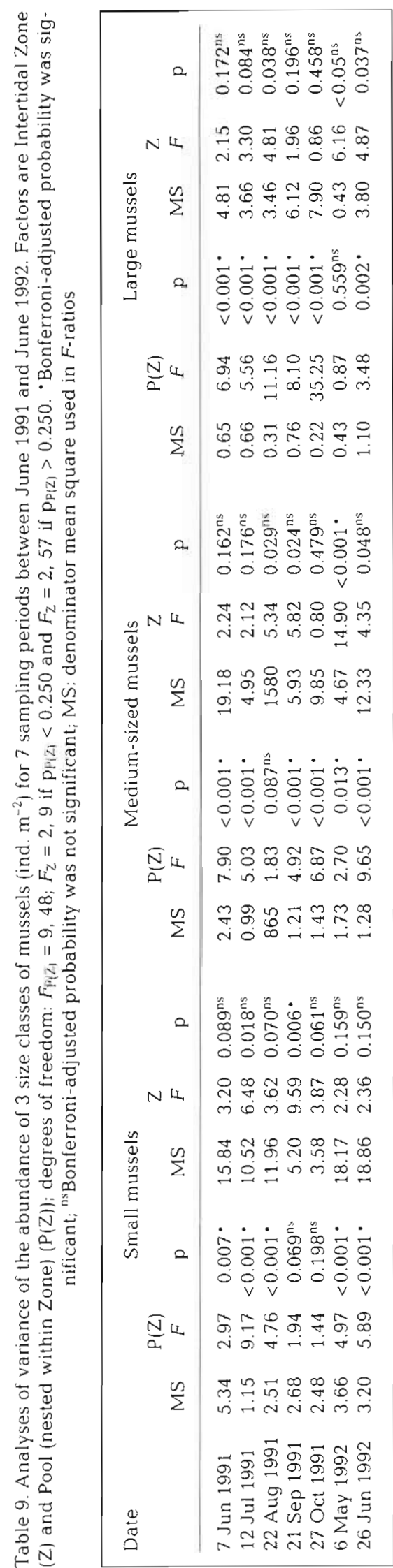


characteristics of individual tidepools. Although the significant independent factors differed among phytoplankton groups, we obtained similar relationships between the abundances at the surface and at the bottom of the pools for each group, but not for total phytoplankton (Table 11). Among the biotic factors, the abundance of total phytoplankton at the bottom, and of pennate diatoms, cryptomonads and chlorophytes at both strata varied significantly with the density of small mussels. Only the abundance of chlorophytes at both strata varied significantly with the density of benthic micrograzers. No phytoplankton group showed a significant relationship with the density of planktonic grazers, medium-sized or large mussels.

In terms of nutrients, the abundance of total phytoplankton at the surface of the pools varied significantly with the concentration of nitrate+nitrite, and the abundance of centric diatoms at the surface and chlorophytes at both strata varied significantly with the concentration of ammonium. Only the abundance of chlorophytes at the bottom of the pools varied significantly with the concentration of phosphate. The abundance of total phytoplankton, cryptomonads and chlorophytes at both strata, and of pennate diatoms at the bottom of the pools varied significantly with the concentration of silicate.

Fewer significant relationships were detected between abiotic factors and the abundance of phytoplankton over the entire sampling period. The abundance of total phytoplankton and chlorophytes at the bottom of the pools and of cryptomonads at both strata varied significantly with temperature. The abundance

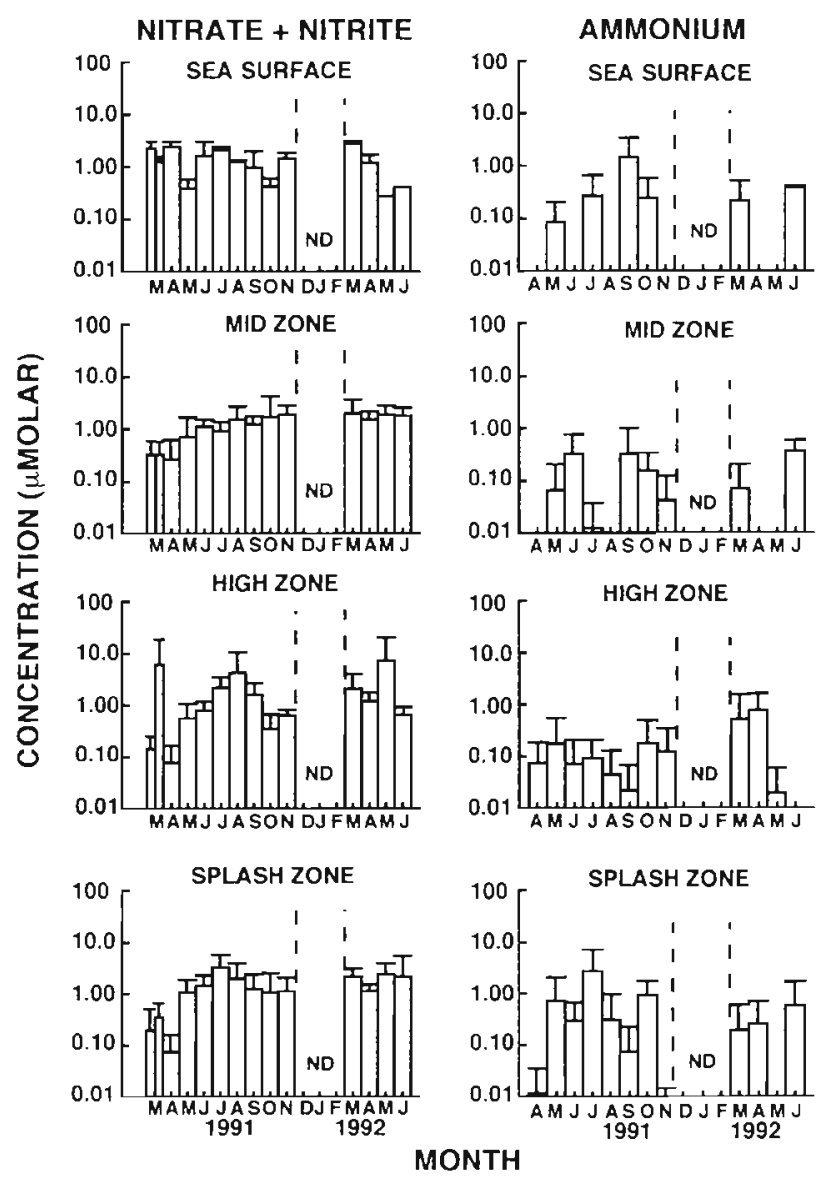

Fig. 10. Mean concentration of nitrate+nitrite and ammonium $( \pm \mathrm{SD})$ at the sea surface $(n=2)$ and at the surface and bottom of tidepools ( $n=4)$ in 3 intertidal zones (mid, high, splash) at Cranberry Cove, Nova Scotia, sampled at approximately monthly intervals between March and November 1991 and March and June 1992 (twice during the bloom in March 1991). ND: no data
SILICATE
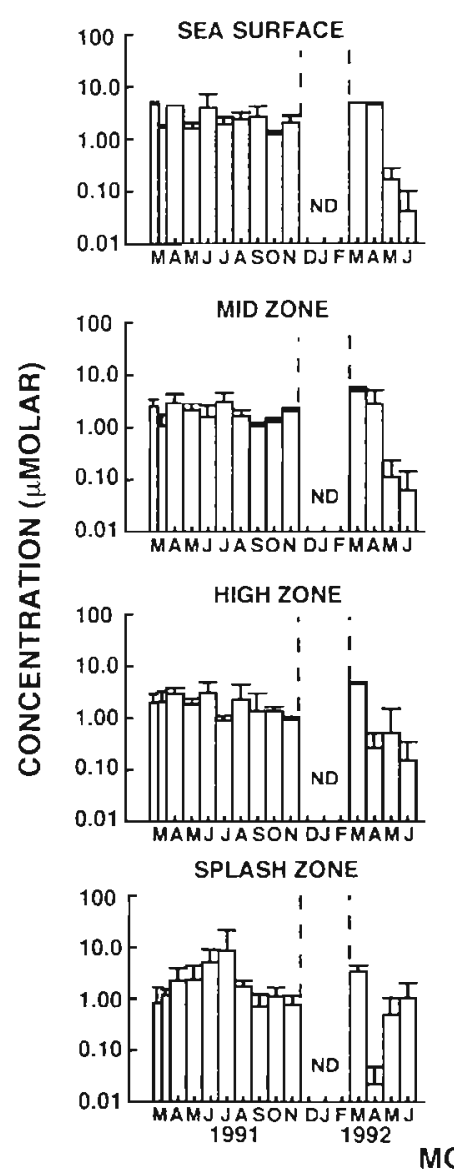

MONTH

Fig. 11 Mean concentration of silicate and phosphate ( \pm SD) at the sea surface $(n=2)$ and at the surface and bottom of tidepools ( $n=4$ ) in 3 intertidal zones (mid, high, splash) at Cranberry Cove, Nova Scotia, sampled at approximately monthly intervals between March and November 1991 and March and June 1992 (twice during the bloom in March 1991). ND: no data 


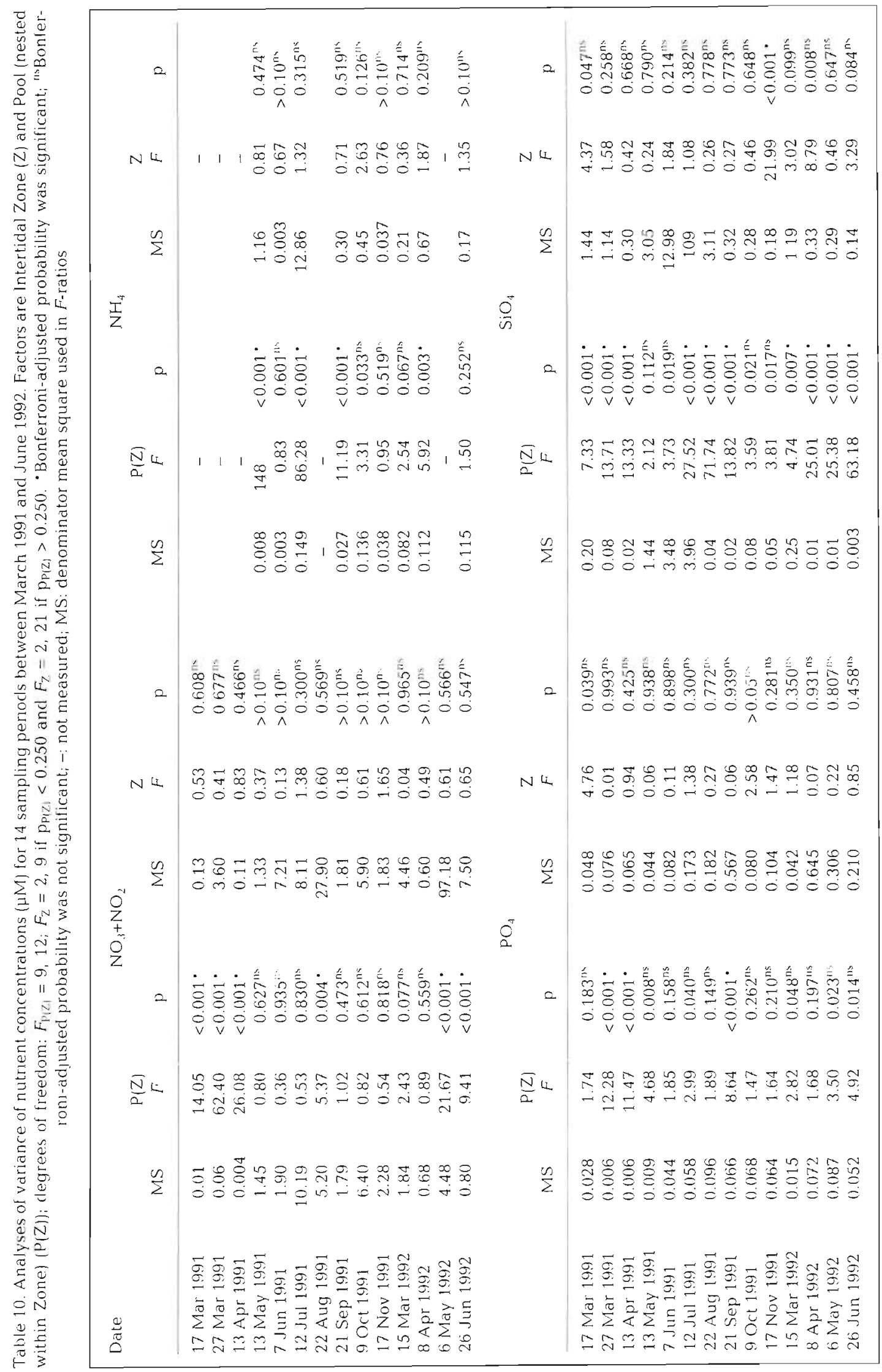


Table 11. Significant forward stepwise multiple regressions for abundance of 5 phytoplankton groups at the surface and near the bottom of tidepools against the biotic and abiotic characteristics of the pools for the entire sampling period between March 1991 and June 1992. Independent variables are: (PL) density of planktonic grazers; (BE) density of benthic grazers; (M<1) density of small mussels; (M1-2) density of medium mussels; (M>2) density of large mussels; (NO) nitrate+nitrite concentration; (NH) ammonium concentration; (PO) phosphate concentration; (Si) silicate concentration; (T) temperature; (S) salinity; (pH) pH; (AL) macroalgal cover; $(H)$ height above chart datum; $(V)$ volume; $(F)$ flushing rate. Within each multiple regression, constants and independent variables with significant partal $F$-values are shown in bold

\begin{tabular}{|c|c|c|c|c|c|}
\hline Dependent variable & N & Model & $\mathrm{R}^{2}$ & F & $\mathrm{p}$ \\
\hline Total phytoplankton (surface) & 168 & $11.52+0.61(\mathrm{NO})-1.00(\mathbf{S i})+0.01(\mathrm{~T})+0.03(\mathrm{~S})$ & 0.054 & 3.38 & $<0.05$ \\
\hline Total phytoplankton (bottom) & 106 & $\begin{array}{l}6.60+0.31(\mathrm{M}<1)+0.54(\mathrm{NO})-1.43(\mathrm{Si})+0.07(\mathrm{~T}) \\
-0.08(\mathrm{~S})+0.82(\mathrm{pH})-0.01(\mathrm{~F})\end{array}$ & 0.247 & 5.92 & $<0.001$ \\
\hline Centric diatoms (surface) & 144 & $3.60-3.84(\mathrm{NH})$ & 0.028 & 5.06 & $<0.05$ \\
\hline Pennate diatoms (surface) & 132 & $6.05-0.12(\mathrm{PL})+0.26(\mathrm{M}<1)+0.82(\mathrm{NO})-0.68(\mathrm{Si})+0.03(\mathrm{AL})$ & 0.171 & 6.39 & $<0.001$ \\
\hline Pennate diatoms (bottom) & 132 & $4.67-0.03(\mathrm{PL})+0.46(\mathrm{M}<1)-1.24(\mathrm{Si})+0.06(\mathrm{~S})+0.04(\mathrm{AL})$ & 0.217 & 8.27 & $<0.001$ \\
\hline Cryptomonads (surface) & 168 & $9.79+0.32(\mathrm{M}<1)+0.30(\mathrm{NO})-0.87(\mathrm{Si})+0.13(\mathrm{~T})-0.04(\mathrm{~F})$ & 0.259 & 12.69 & $<0.001$ \\
\hline Cryptomonads (bottom) & 168 & $\begin{array}{l}10.81+0.26(\mathrm{M}<1)+0.82(\mathrm{NO})-1.81(\mathrm{PO}) \\
-0.92(\mathrm{Si})+0.10(\mathrm{~T})-0.04(\mathrm{~F})\end{array}$ & 0.220 & 8.83 & $<0.001$ \\
\hline Chlorophytes (surface) & 132 & $\begin{array}{l}16.00-1.06(\mathrm{BE})-0.56(\mathrm{M}<1)+5.36(\mathrm{NH})+3.89(\mathrm{PO}) \\
-2.10(\mathrm{Si})-0.06(\mathrm{~S})+0.04(\mathrm{AL})\end{array}$ & 0.393 & 4.29 & $<0.001$ \\
\hline Chlorophytes (bottom) & 132 & $\begin{array}{l}16.39+0.08(\mathrm{PL})-0.61(\mathrm{BE})-0.60(\mathrm{M}<1)+4.58(\mathrm{NH}) \\
+4.80(\mathrm{PO})-2.53(\mathrm{Si})-0.07(\mathrm{~S})-0.23(\mathrm{~T})+0.04(\mathrm{AL})\end{array}$ & 0.450 & 12.93 & $<0.001$ \\
\hline
\end{tabular}

of total phytoplankton at the bottom of the pools varied significantly with salinity. The abundance of pennate diatoms and chlorophytes at both strata varied significantly with percentage cover of macroalgae, and the abundance of cryptomonads at both strata varied significantly with flushing rate.

\section{DISCUSSION}

Phytoplankton succession at the sea surface followed a pattern previously described for Nova Scotia (Côté \& Platt 1983, Perry et al. 1989) and north temperate waters elsewhere (Harrison et al. 1983, Reid et al. 1990, Haigh et al. 1992, Weeks et al. 1993). The spring blooms in 1991 and 1992 were dominated by the centric diatoms Chaetoceros spp. and Skeletonema costatum, and the autumn bloom in 1991 was dominated by the centric diatom Rhizosolenia. After the spring blooms, the abundance of pennate diatoms, flagellates and nanoflagellates increased in May/June in both years.

In tidepools, cryptomonads and chlorophytes were the numerically dominant groups of phytoplankton throughout the sampling period. Centric diatoms were introduced into pools during the blooms and their abundance subsequently decreased: Since tidepools and splash pools are less turbulent environments than the surrounding seawater, the difference in dominance patterns between the sea surface and the tidepools is consistent with Margalef's proposal (1978) that under conditions of high turbulence centric and pennate diatoms should dominate, whereas under low turbu- lence flagellates should dominate (see also Kiørboe 1993 for review). Cryptomonads are characterized as opportunistic with wide temperature and salinity tolerances (Klaveness 1988), which also may explain their numerical dominance in tidepools.

We examined 3 sources of spatial variability of the phytoplankton assemblages of tidepools: (1) between strata (the surface and bottom of pools), (2) among intertidal zones, and (3) among pools within zones. The magnitude of variability between strata differed among phytoplankton groups and reflected the characteristics of individual life forms. The largest number of significant differences between strata were detected for pennate diatoms, a group which is mostly benthic. On most dates, the factor stratum accounted for 30 to $40 \%$ of the variance in the abundance of pennate diatoms. In all cases except for on 27 March 1991, the abundance of pennate diatoms was greater at the bottom than at the surface of the pools. We detected fewer differences in abundance between strata for centric diatoms, cryptomonads and chlorophytes than for pennate diatoms, probably because centric diatoms are more buoyant and cryptomonads and chlorophytes are more motile than pennate diatoms. In most cases, these 3 taxonomic groups were more abundant at the bottom of the pools, probably due to sinking.

We found no indication of intertidal zonation of phytoplankton assemblages in tidepools. Dethier (1982) recorded zonation of diatoms (mainly pennates) along the intertidal gradient, which appeared to reverse during the year. She observed diatom blooms in lower pools in summer and in higher pools in winter, which 
she attributed to reduced grazer densities in those zones during those periods (Dethier 1982, 1984). Metaxas \& Lewis (1992) observed a decline in the abundance of centric diatoms and an increase in the abundance of pennates in pools of increasing intertidal height. The difference between these studies and ours could be the result of wave exposure: the site described in Metaxas \& Lewis (1992) was very protected, whereas our site was very exposed. Dethier (1984) also observed less zonation of microalgae in the more exposed sites of her study.

Significant differences among zones in abiotic and biotic factors that may affect phytoplankton abundance were observed on some sampling dates. The lack of differences among intertidal zones in the abundance of phytoplankton suggest that these assemblages do not show vertical zonation. Since there were few differences among zones in the abiotic and biotic factors that potentially regulate these assemblages, we suggest that variability in these factors does not adequately explain variability in abundance of phytoplankton on the vertical scale

Spatial variability in the abundance of phytoplankton among pools within intertidal zones was detected consistently for all phytoplankton groups on most sampling dates. For total phytoplankton, and for cryptomonads and chlorophytes, up to $96 \%$ of the variance in abundance was explained by variability along the horizontal scale. For centric and pennate diatoms, variability within zones was at least as large as variability among intertidal zones, and on some dates it was larger. The biotic factors that could affect phytoplankton abundance also varied significantly within zones on most sampling dates. We have documented previously that the hyperbenthic and macrobenthic assemblages of these pools exhibit large variability within zones, suggesting that individual pools are unique in the combination of their biotic and abiotic characteristics (Metaxas \& Scheibling 1994a, Metaxas et al. 1994). Therefore, the factors regulating phytoplankton assemblages in tidepools probably operate more at the scale of the individual pool rather than the intertidal 7.one

Multiple regressions showed significant relationships in all but 1 group of phytoplankton (centric diatoms), both at the surface and the bottom of the pools, with some biotic and abiotic characteristics of the pools. The lack of relationships with the abundance of centric diatoms is probably because diatoms are more transient residents of the pools (they are mainly introduced during blooms in the surrounding seawater) than are the other groups. Nutrients showed significant relationships with the abundance of most phytoplankton groups. The relationship between the abundance of phytoplankton and the concentration of silicate was negative for all phytoplankton groups. For pennate diatoms, the relationship may be attributed to nutrient uptake. Since cryptomonads and chlorophytes do not require silicate for growth, no direct mechanism for the relationship can be suggested. The relationships between the abundance of chlorophytes and the concentration of phosphate and ammonium were positive.

Certain grazers also showed significant relationships with the abundance of phytoplankton. The abundance of all phytoplankton groups (except centric diatoms) varied significantly with the density of small mussels, but only chlorophytes showed a significant relationship with benthic micrograzers, and there were no relationships with medium-sized, large mussels or planktonic micrograzers. The relationships between the abundance of pennate diatoms and cryptomonads and the density of small mussels were positive, suggesting that mussels in that size class are more abundant in pools where a potential food source is more abundant or that both phytoplankton and small mussels are responding positively to some other factor. However, the relationships between the abundance of chlorophytes and the density of small mussels and benthic micrograzers were negative, suggesting that these grazers may be significantly removing this group of phytoplankton by feeding. The lack of significant relationships between the abundance of phytoplankton and the density of planktonic grazers, medium-sized and large mussels suggest that these factors are not important and/or that their importance may vary during the year The role of planktonic grazers, such as calanoid copepods, cladocerans and rotifers, in determining the phytoplankton community structure of oceanic systems has not been demonstrated consistently (e.g Deason 1980, Estep et al. 1990, Hansen \& van Boekel 1991, Morales et al. 1991, but see also Conover \& Mayzaud 1984). In contrast, the abundance of phytoplankton in restricted water masses can be reduced substantially by mussel beds during 1 tidal cycle (e.g. Wright et al. 1982. Fréchette et al. 1989, Asmus \& Asmus 1991).

Fewer significant relationships were detected between the abiotic characteristics of the pools and the abundance of phytoplankton. Temperature and flushing rate were important factors for cryptomonads and chlorophytes, and percentage cover of macroalgae for pennate diatoms and chlorophytes. A positive relationship between temperature and the abundance of cryptomonads reflects the increase in abundance of this group in summer, whereas a negative relationship between temperature and the abundance of chlorophytes reflects the increase of this group in fall. A negative relationship between flushing rate and the abundance of cryptomonads reinforces the suggestion that 
they are the dominant phytoplankton group in tidepools because pools are low-turbulence environments. A positive relationship between pennate diatoms and macroalgae suggests that macroalgae enhance settlement of this group by increasing the surface area upon which pennate diatoms (especially epiphytic species) can settle (see Round 1971 for review)

In summary, we examined the sources of vertical and horizontal spatial variability of phytoplankton assemblages in tidepools. We did not detect strong patterns of zonation in tidepools across the intertidal gradient, and the potential abiotic and biotic factors regulating these assemblages did not adequately describe variability at this spatial scale. Conversely, a large amount of the variance in phytoplankton abundance was attributed to variability on the horizontal spatial scale, within zones. At this scale, the biotic characteristics of individual pools explained some of the variability in phytoplankton abundance, although abiotic factors did not appear as important. Certain components of the grazer communities of each pool explained some of the variance in phytoplankton abundance for all phytoplankton groups except centric diatoms. The nutrient regime also was an important factor for all groups although the relative importance of different nutrients varied among phytoplankton groups. Our study underscores the importance of assessing the different sources of spatial variability in the successful explanation of patterns of community organization.

Acknowledgements. We thank Brian Dixon, Heather Hunt, Laurence McCook, Todd Minchinton, Ellen Pedersen and Don Webb for assisting in sample collection. Pierre Clement at the Marine Chemistry Division of the Department of Fisheries and Oceans at the Bedford Institute of Oceanography (Dartmouth, Nova Scotia, Canada) analyzed the nutrient samples for nitrate+nitrite, phosphate and silicate. Drs A. R. O. Chapman, B. G. Hatcher, S. Hawkins, S. Walde and D. G. Webb critically read earlier drafts of the manuscript. A.M. was supported by a postgraduate scholarship from the 'Alexander S. Onassis' Public Benefit Foundation (A.thens, Greece) and scholarships from the Faculty of Graduate Studies, Dalhousie University. The research was funded by a Natural Sciences and Engineering Research Council Operating Grant to R.E.S

\section{LITERATURE CITED}

Addicott JF, Aho JM, Antolin MF, Padilla DK, Richardson JS, Soluk DA (1987) Ecological neighbourhoods: scaling environmental patterns. Oikos 49:340-346

Aleem AA (1950) Distribution and ecology of British marine littoral diatoms. Ecology 38:75-106

Andrew NL, Mapstone BD (1987) Sampling and the description of spatial pattern in marine ecology. Oceanogr mar Biol A Rev 25:39-90

Asmus RM, Asmus H (1.991). Mussel beds: limiting or promoting phytoplankton? J exp mar Biol Ecol 148:215-232
Barnes RD (1980) Invertebrate zoology, 2nd edn. Saunders College, Philadelphia

Brinkhurst RO, Linkletter LE, Lord EI, Connors SA, Dadswell MJ (1976) A preliminary guide to the littoral and sublittoral invertebrates of Passamaquoddy Bay. Identification Center, Department of the Environment, Fisheries and Marine Service, Biological Station, St. Andrews, NB

Caffey HM (1985) Spatial and temporal variation in settlement and recruitment of intertidal barnacles. Ecol Monogr 55:313-332

Castenholz RW (1963) An experimental study of the vertical distribution of littoral marine diatoms. Limnol Oceanogr 4 : $450-462$

Chrétiennot-Dinet MJ (1990) Atlas du phytoplanctón marin, Vol 3: chlorarachriophycées, chlorophycées, chrysophycées, cryptophycées, euglénophycées, eustigmatophycées, prasinophycées, prymnésiophycées, rhodophycées, tribophycées. Editions du CNRS, Paris

Connell JH (1961) The influence of interspecific competition and other factors on the distribution of the barnacle Chthamalus stellatus. Ecology 42:710-723

Connell JH (1972) Community interactions on marine rocky intertidal shores. A Rev Ecol Syst 3:169-192

Connell JH (1983) On the prevalence and relative importance of interspecific competition: evidence from field experiments. Am Nat 122:661-696

Conover RJ, Mayzaud P (1984) Utilization of phytoplankton by zooplankton during the spring bloom in a Nova Scotia inlet. Can J Fish aquat Sci 41:232-244

Côté B, Platt $T$ (1983) Day-to-day variations in the springsummer photosynthetic parameters of coastal marine phytoplankton. Limnol Oceanogr 28:320-344

Cupp EE (1943) Marine plankton diatoms of the west coast of North America. University of California Press, Berkeley

Dayton PK (1971) Competition, disturbance, and community organization: the provision and subsequent utilization of space in a rocky intertidal community. Ecol Monogr 41:351-389

Deason EE (1980) Grazing of Acartia hudsonica (A. clausil) on Skeletonema costatum in Narragansett Bay (USA): influence of food concentration and temperature. Mar Biol 60: $101-113$

Denley EJ, Underwood AJ (1979) Experiments on factors influencing settlement, survival, and growth of two species of barnacles in New South Wales. J exp mar Biol Ecol 36:269-293

Dethier MN (1982) Pattern and process in tidepool algae: factors influencing seasonality and distribution. Botanica mar 25:55-66

Dethier MN (1984) Disturbance and recovery in intertidal pools maintenance of mosaic patterns. Ecol Monogr 54:99-118

Downes BJ, Lake PS, Schreiber ESG (1993) Spatial variation in the distribution of stream invertebrates: implications of patchiness for models of community organization. Freshwat Biol 30:119-132

Droop MR (1953) On the ecology of flagellates from some brackish and fresh water rockpools of Finland. Acta bot fenn 51:1-52

Estep KW, Nejstgaard JC, Skjoldal HR, Rey F (1990) Predation by copepods upon natural populations of Phaeocystis pouchetii as a function of the physiological state of the prey. Mar Ecol Prog Ser 67:235-249

Foster MS (1990) Organization of macroalgal assemblages in the Northeast Pacific: the assumption of homogeneity and the illusion of generality. Hydrobiologia 192:21-33

Fréchette M, Butman CA, Geyer WR (1989) The importance of boundary-layer flows in supplying phytoplankton to the 
benthic suspension feeder, Mytilus edulis L. Limnol Oceanogr 34:19-36

Gardner GA, Szabo I (1982) British Columbia pelagic marine copepoda: an identification manual and annotated biblıography. Can Spec Publ Fish Aquat Sci 62

Gervais F (1991) Which factors controlled seasonal and spatial distribution of phytoplankton species in Schlachtensee (Berlin, F.R.G.) 1987? Arch Hydrobiol 121:43-65

Haigh R, Taylor FJR, Sutherland TF (1992) Phytoplankton ecology of Sechelt Inlet, a fjord system on the British Columbia coast. I. General features of the nano- and microplankton. Mar Ecol Prog Ser 89:117-134

Hansen FC, van Boekel WHM (1991) Grazing pressure of the calanoid copepod Temora longicornis on a Phaeocystis dominated spring bloom in a Dutch tidal inlet. Mar Ecol Prog Ser 78:123-129

Harrison PJ, Fulton JD, Taylor FJR, Parsons TR (1983) Review of the biological oceanography of the Strait of Georgia: pelagic environment. Can J Fish Aquat Sci 40:1064-1094

Hendey NI (1964) An introductory account of the smaller algae of British coastal waters. Part V: Baccilariophyceae (diatoms). Ministry of Agriculture, Fisheries and Food, Fisheries Investigations Series IV, HMSO, London

Hill AS, Hawkins SJ (1991) Seasonal and spatial variation of epilithic microalgal distribution and abundance and its ingestion by Patella vulgata on a moderately exposed rocky shore. J mar biol A.ss UK 71:403-423

Hobson LA (1988/1989) Paradox of the phytoplankton - an overview. Biol Oceanogr 6:493-504

Hopkins JT (1964) A study of the diatoms of the Ouse estuary, Sussex. IIl. The seasonal variation in the littoral epiphyte flora and the shore plankton. J mar biol Ass UK 44:613-644

Howell DC (1987) Statistical methods for psychology. Duxbury Press, Boston

Jernakoff P. Fairweather PG (1985) An experimental analysis of interactions among several intertidal organisms. J exp mar Biol Ecol 94:71-88

Kemp PF, Newell SY, Krambeck C (1990) Effects of filterfeeding by the ribbed mussel Geukensia demissa on the water-column microbiota of a Spartina alterniflora saltmarsh. Mar Ecol Prog Ser 59:119-131

Kiorboe T (1993) Turbulence, phytoplankton cell size, and the structure of pelagic food webs. Adv mar Biol 29:1-72

Klaveness D (1988) Ecology of the cryptomonida: a first review. In: Sandgren CD (ed) Growth and reproductive strategies of freshwater phytoplankton. Cambridge University Press, Cambridge, p 105-133

Kleinbaum DG, Kupper LL, Muller KE (1988) Applied regression analysis and other multivariable methods. PWS. KENT Publishing Company, Boston

Levin SA (1992) The problem of pattern and scale in ecology. Ecology 73:1943-1967

Lively CM, Raimondi PT, Delph LF (1993) Intertıdal community structure: space-tme interactions in the northern Gulf of California. Ecology 74:162-173

Lubchenco J, Menge BA (1978) Community development and persistence in a low rocky untertidal zone. Ecol Monogr 48 : $67-94$

Lund JWG, Kipling C, Le Cren ED (1958) The inverted microscope method of estimating a lgal numbers and the statistical basis of estumations by counting. Hydrobiologia 11:143-170

MacLulich JH (1986) Colonization of bare rock surfaces by microflora in a rocky intertıdal habitat. Mar Ecol Prog Ser 32:91-.96

Margalef R (1978) Life-forms of phytoplankton as survival alternatives in an unstable environment. Oceanol Acta 1: $493-509$
McGuinness KA (1987a) Disturbance and organisms on boul ders. I. Patterns in the environment and the community Oecologia 71:409-419

McGuinness KA (1987b) Disturbance and organisms on boulders. II. Causes of patterns in diversity and abundance Oecologia 71:420-430

Menge BA (1976) Organization of the New England rocky intertidal community: role of predation, competition, and environmental heterogeneity. Ecol Monogr 46:355-393

Metaxas A, Hunt HL, Scheibling RE (1994) Spatial and temporal variability of macrobenthic assemblacges in tidepools on a rocky shore in Nova Scotıa, Canada. Mar Ecol Prog Ser 105:89-103

Metaxas A, Lewis AG (1992) Diatom communities in tidepools: the effect of intertidal height. Botanica mar 35:1-10

Metaxas A, Scheibling RE (1993) Community structure and organization of tidepools. Mar Ecol Prog Ser 98:187-198

Metaxas A, Scheibling RE (1994a) Spatial and temporal variability of tidepool hyperbenthos on a rocky shore in Nova Scotia, Canada. Mar Ecol Prog Ser 108:175-184

Metaxas A, Scheibling RE (1994b) Changes in phytoplankton abundance in tidepools over the period of tidal isolation. Botanica mar 37:301-314

Morales CE, Bedo A, Harris RP, Tranter PRG (1991) Grazing of copepod assemblages in the northeast Atlantic: the importance of the small size fraction. J Plankton Res 13:455-472

Morris DW (1987) Ecological scale and habitat use. Ecology 68:362-369

Paine RT (1966) Food web complexity and species diversity. Am Nat 100:65-75

Paine RT (1974) Intertidal community structure. Experimental studies on the relationship between a dominant competitor and its principal predator. Oecologic 15:93-120

Parsons TR. Harrison PJ, Waters R (1978) An experimental simulation of changes in diatom and flageliate blooms. $J$ exp mar Biol Ecol 32:285-294

Parsons TR, Maita Y, Lalli CM (1984) A manual of chemical and biological methods for seawater analysis. Pergamon Press, Oxford

Perry JN (1988) Some models for spatial variability of animal species. Oikos 51:124-130

Perry RI, Hurley PCF, Smith PC, Koslow JA, Fournier RO (1989) Modelling the initiation of spring phytoplankton blooms: a synthesis of physical and biological interannual variability off southwest Nova Scotia, 1983-85. Can J Fish Aquat Sci 46. Suppl (1):183-199

Pomeroy L (1991). Relationships of primary and secondary production in lakes and marine ecosystems. In: Cole J, Lovett G. Findlay S (eds) Comparative analyses of ecosystem. Patterns, mechanisms, and theories. Springer-Verlag, New York, p 97-119

Reid PC, Lancelot C, Gieskes WWC, Hagmeier E, Weichart G (1990) Phytoplankton of the North Sea and its dynamıcs: a review. Neth J Sea Res 26:295-331

Reynolds CS, Thompson JM, Ferguson AJD, Wiseman SW (1982) Loss processes in the population dynamics of phytoplankton maintained in closed systems. J Plankton Res 4 : $561-600$

Ricard M (1987) Atlas du phytoplancton marin, Vol 2, Diatomaphycées. Editions du CNRS, Pans

Rice WR (1989) Analyzing tables of statistical tests. Evolution. $43: 223-225$

Round FE (1971) Benthic marine diatoms. Oceanogr mar biol A Rev 9:83-139

Schonbeck MW, Norton TA (1978) Factors controlling the upper limits of fucold algae on the shore. J exp mar Biol Ecol 31:303-313 
Smith RI (1964) Keys to marine invertebrates of the Woods Hole region. Contribution No. 11, Systematics-Ecology Program, Manne Biological Laboratory, Woods Hole, Massachusetts. Spaulding Co., Boston

Sokal RR, Rohlf FJ (1981) Biometry, 2nd edn. W. H. Freeman and Company, New York

Sommer U (1991) Phytoplankton: directional succession and forced cycles. In: Remmert $H$ (ed) The mosalc-cycle concept of ecosystems. Springer-Verlag, Berlın, p 132-146

Sournia A. (1986) Atlas du phytoplanctón marin, volume 1. cyanophycées, dictyophycées, dinophycées, raphidophycées. Editions du CNRS, Paris

Sousa WP (1979) Experımental investigations of disturbance and ecological succession in a rocky intertidal algal community. Ecol Monogr 49:227-254

Sousa WP (1984a) Intertidal mosaics: patch size, propagule availability, and spatially variable patterns of succession. Ecology 65:1918-1935

Sousa WP (1984b) The role of disturbance in natural communities. A Rev Ecol Syst 15:353-391

Stephenson TA, Stephenson A (1950) Life between tide-marks in North America. I. The Florida Keys. J Ecol 38:354-402

Stephenson TA, Stephenson A (1952). Life between tidemarks in North America. II. Northern Florida and the Carolinas. J Ecol 40:1-49

Stephenson TA, Stephenson A (1954a) Life between tidemarks in North America. IIIA. Nova Scotia and Prince Edward Island: description of the region. J Ecol 42:14-45

Stephenson TA, Stephenson A (1954b) Life between tidemarks in North America. IllB. Nova Scotıa and Prince Edward Island: the geographical features of the region. J Ecol 42:46-70

Tilman D (1977) Resource competition between planktonıc algae: an experimental and theoretical approach. Ecology 58:338-348

Underwood AJ (1981a) Structure of the rocky intertidal community in New South Wales: patterns of vertical distrubution and seasonal changes. J exp mar Bıol Ecol 51:57-85

This article was presented by R. N. Hughes (Senior Editorial Advisor), Bangor, United Kingdom
Underwood AJ (1981b) Techniques of analysis of variance in experimental biology and ecology. Oceanogr mar Biol A. Rev 19:513-605

Underwood AJ, Denley EJ (1984) Páradigms, explanations, and generalizations in models for the structure of intertidal communities on rocky shores. In: Strong DR Jr, Simberloff D, Abele LG, Thistle AB (eds) Ecological communities: conceptual issues and the evidence. Princeton University Press, Princeton, p 151-180

Vanni M. Temte J (1990) Srasonal patterns of grazing and nutrent limitation of phytoplankton in a eutrophic lake. Limnol Oceanogr 35:697-709

Venrick EL (1990) Phytoplankton in an oligotrophic ocean: species structure and interannual variability. Ecology 71 : $1547-1563$

Wassman P (1991) Dynamics of primary production and sedimentation in shallow fjords and polls of western Norway. Oceanogr mar Biol A Rev 29:87-154

Weeks AR, Fasham MJR, Aiken J, Harbour DS, Read JF, Bellan 1 (1993) The spatial and temporal development of the spring bloom during the JGOFS North Atlantic bloom experiment, 1989. J mar biol Ass UK 73:253-282

Wiegert RG (1988) Holism and reductionism in ecology: hypotheses, scale and systems models. Oikos 53:267-269

Wiens JA (1989) Spatial scaling in ecology. Funct Ecol 3; $385-397$

Wilkinson L (1989) SYSTAT: the system for statistics. SYSTAT Inc., Evanston, IL

Winer BJ (1971) Statistical principles in experimental design. McGraw-Hill, New York

Winter JE (1973) The filtration rate of Mytilus edulis and its dependence on algal concentration, measured by a continuous automatic recording apparatus. Mar Biol 22: $317-328$

Wright RT, Coffin RB, Ersing CP, Pearson D (1982) Field and laboratory measurements of bivalve fitration of natural marine bacterioplankton. Limnol Oceanogr 27 $91-98$

Manuscript first received: March 30, 1995

Revised version accepted: July 6, 1995 